\title{
Towards Closing the Polar Gap: New Marine Heat Flow Observations in Antarctica and the Arctic Ocean
}

\author{
Ricarda Dziadek ${ }^{1, *(D)}$, Mechthild Doll ${ }^{2}$, Fynn Warnke ${ }^{1}$ (D) and Vera Schlindwein ${ }^{1}$ \\ 1 Alfred Wegener Institute-Helmholtz Centre for Polar and Marine Research, Am Alten Hafen 26, \\ 27568 Bremerhaven, Germany; fynn.warnke@awi.de (F.W.); vera.schlindwein@awi.de (V.S.) \\ 2 Department of Geosciences, University of Bremen, Klagenfurter Street 2-4, 28359 Bremen, Germany; \\ s_3oo8ut@uni-bremen.de \\ * Correspondence: ricarda.dziadek@awi.de; Tel.: +49-(471)-4831-2425
}

Citation: Dziadek, R.; Doll, M.; Warnke, F.; Schlindwein, V. Towards Closing the Polar Gap: New Marine Heat Flow Observations in Antarctica and the Arctic Ocean. Geosciences 2021, 11, 11 .

https://dx.doi.org/10.3390/ geosciences 11010011

Received: 10 November 2020 Accepted: 21 December 2020 Published: 27 December 2020

Publisher's Note: MDPI stays neutral with regard to jurisdictional claims in published maps and institutional affiliations.

Copyright: () 2020 by the authors. Licensee MDPI, Basel, Switzerland. This article is an open access article distributed under the terms and conditions of the Creative Commons Attribution (CC BY) license (https: / / creativecommons.org/ licenses/by/4.0/).

\begin{abstract}
The thermal state of the lithosphere and related geothermal heat flow (GHF) is a crucial parameter to understand a variety of processes related to cryospheric, geospheric, and/or biospheric interactions. Indirect estimates of GHF in polar regions from magnetic, seismological, or petrological data often show large discrepancies when compared to thermal in situ observations. Here, the lack of in situ data represents a fundamental limitation for both investigating thermal processes of the lithosphere and validating indirect heat flow estimates. During RV Polarstern expeditions PS86 and PS118, we obtained in situ thermal measurements and present the derived GHF in key regions, such as the Antarctic Peninsula and the Gakkel Ridge in the Arctic. By comparison with indirect models, our results indicate (1) elevated geothermal heat flow $\left(75 \pm 5 \mathrm{~mW} \mathrm{~m}^{-2}\right.$ to $\left.139 \pm 26 \mathrm{~mW} \mathrm{~m}^{-2}\right)$ to the west of the Antarctic Peninsula, which should be considered for future investigations of ice-sheet dynamics and the visco-elastic behavior of the crust. (2) The thermal signature of the Powell Basin characteristic for oceanic crust of an age between 32 and 18 Ma. Further, we propose (3) that at different heat sources at the slow-spreading Gakkel Ridge in the Aurora Vent Field region might explain the geothermal heat flow distribution. We conclude that in situ observations are urgently required to ground-truth and fine-tune existing models and that a multidisciplinary approach is of high importance for the scientific community's understanding of this parameter.
\end{abstract}

Keywords: geothermal heat flow; in situ temperature measurements; Antarctica; Arctic Ocean; Weddell Sea; Powell Basin; Gakkel Ridge; Aurora Vent Field

\section{Introduction}

Polar regions play a vital role in Earth systems because of their profound influence on planetary climate, ocean systems, support areas of pristine ecology, and geological processes. In situ temperature observations for deriving geothermal heat flow are extremely sparse in these regions, because of their remoteness and challenging climatic conditions characterizing these study areas. These observations however present crucial thermal boundary conditions for ice sheet or permafrost models, and related sea level rise predictions. Moreover, temperature measurements are urgently required to study geodynamic and tectonic processes, subglacial lakes, hydrologic networks and ecosystems beneath ice sheets or along mid-ocean ridges that remain largely unexplored.

During several RV Polarstern expeditions, a suite of in situ temperature measurements were collected for estimating geothermal heat flow in key polar regions, such as the western Weddell Sea in Antarctica and along the Gakkel Ridge in the Arctic Ocean.

The Scientific Committee on Antarctic Research (SCAR) formulated the most important scientific questions in a horizon scan, which includes the investigation of geothermal heat flow in Antarctica [1]. Recently, the scientific community has highlighted a strong need for a multidisciplinary and internationally-coordinated approach to tackle this complex 
problem [2]. However, geothermal heat flow remains poorly constrained, and there are large discrepancies in currently available glaciological and geophysical estimates.

RV Polarstern Expedition PS118 [3] targeted the Larsen C ice shelf in the western Weddell Sea (Figure 1a,b), which is part of the Antarctic Peninsula and among the fastest warming regions globally [4]. In July 2017, the ice shelf calved iceberg A68 [5], one of the largest icebergs ever recorded, with the resulting landward shift of the ice-edge having a profound effect on environmental factors and ecosystems in previously covered areas. Heavy sea ice conditions in the austral summer 2019 however forced RV Polarstern to abandon the target area and return to other areas of interest such as Larsen A and the Powell Basin (see ship track marked in yellow in Figure 1b).
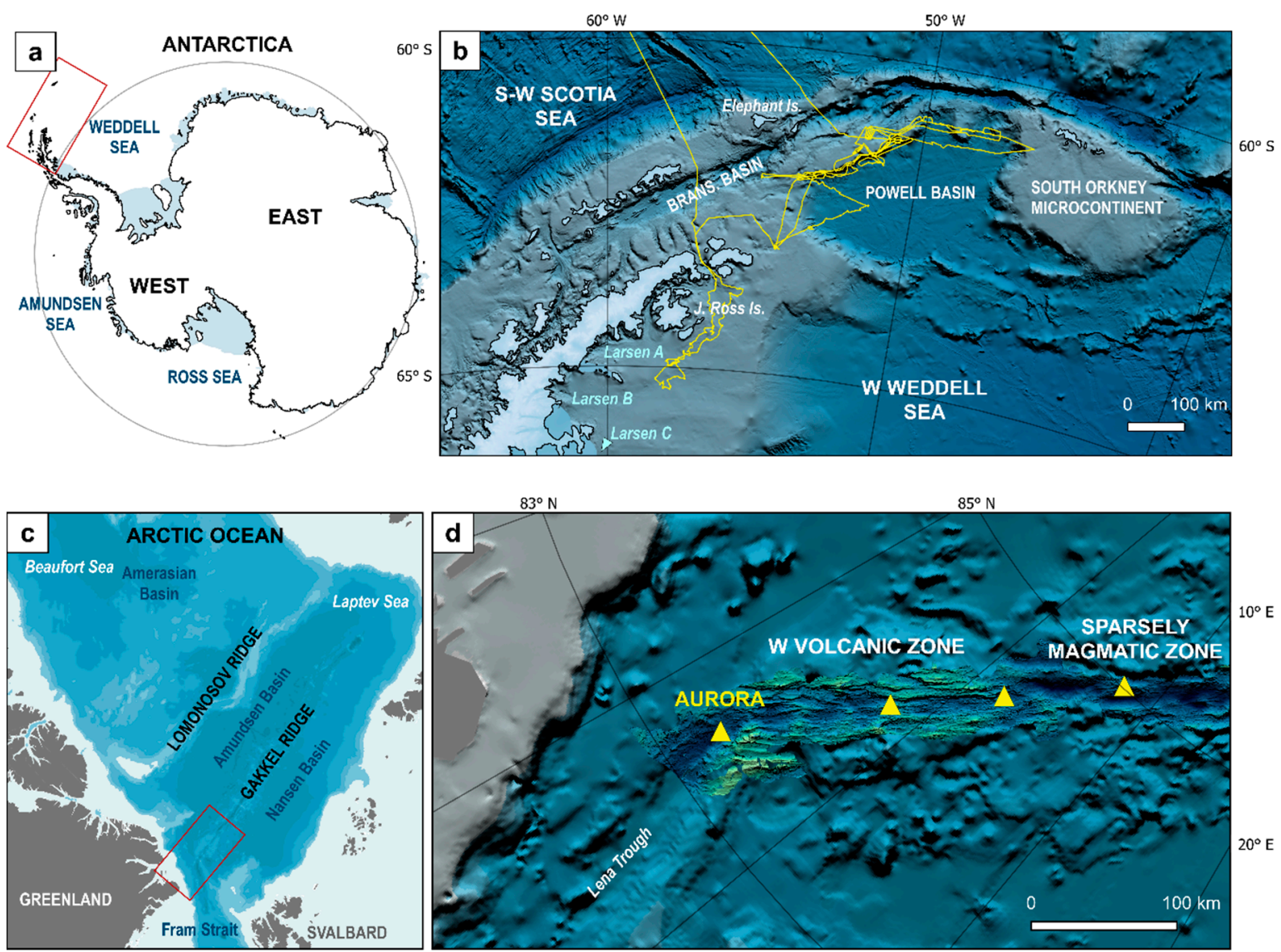

Figure 1. (a) Overview map of Antarctica, Antarctic Circle, and the working area marked with a red box. Polarstern Expedition PS118 targeted the western Weddell Sea, which is bound by the Antarctic Peninsula to the west. (b) Close up of the working area and the ships track highlighted in yellow. Elevation is from BedMachine Antarctica [6]. (c) Overview map of the Arctic Ocean, location of the Gakkel Ridge, and the working area bound by a red box. (d) Close up of the working area in the Western Volcanic Zone of the Gakkel Ridge and locations of identified vent fields [7] marked by yellow triangles. The Aurora Vent Field is located in the western part of the volcanic zone towards Lena trough. Low-resolution bathymetry is the International Bathymetric Chart of the Arctic Ocean (IBCAO) [8] and high-resolution bathymetry from [7].

Marine geothermal heat flow estimates and in situ temperature measurements are absent from the entire region, with glaciological measurements on James Ross Island [9] and the Antarctic Peninsula [10] indicating a large discrepancy between observations and existing indirect, regional, and continental models [11-14].

Ultraslow spreading occurs at Gakkel Ridge and at the Southwest Indian Ridge, both known to be seismically active, but little is understood about their hydrothermal vent systems. The lithosphere of ultraslow spreading ridges is expected to be significantly thicker than at faster spreading ridges [15] varying strongly along axis [16,17]. Conductive cooling of the upwelling mantle material reduces the amount of melt produced [18]. 
Little is known how anomalously frequent hydrothermal vent systems at ultraslow spreading ridges [19] can be supplied with heat under these circumstances.

Expedition PS86 targeted the Aurora hydrothermal vent field (Figure 1c,d), located near the southern end of the Western Volcanic Zone (WVZ, $82^{\circ} 53^{\prime} \mathrm{N}, 6^{\circ} 15^{\prime} \mathrm{W}$ ) at over $4000 \mathrm{~m}$ water depth [20]. The vent field was discovered during the AMORE expedition in 2001, by detecting hydrothermal fluids in the water column, sampling sulfide chimneys during dredging and by recording seabed video footage [21]. The study area presents a unique location for investigating the interaction between solid earth and the overlying ocean, as well as with the biosphere living at the seafloor.

The aim of this study is to report geothermal heat flow estimates from the Weddell Sea, Powell Basin, and western Gakkel Ridge, compare them to existing indirect models, and discuss their implications.

\section{Materials and Methods}

\subsection{Thermal Measurements}

During RV Polarstern Expedition PS118 [3] in the Weddell Sea, temperatures were measured with miniaturized temperature data-loggers (MTL) mounted on a metal lance or gravity corer, with $0.001 \mathrm{~K}$ resolution and $0.1 \mathrm{~K}$ precision [22]. The mounting geometry (Figure $2 \mathrm{~b}$ ) allows inferring the temperature gradient. The deployment procedure for these lance or gravity corer based thermal probe is similar to gravity coring. Prior to deployment, the MTLs were calibrated for absolute temperatures with the ships SBE911plus CTD (conductivity, temperature, and depth) in the water column. After calibration, the offset between MTL and CTD was $\pm 0.001 \mathrm{~K}$, which is within the overall resolution of the MTL.
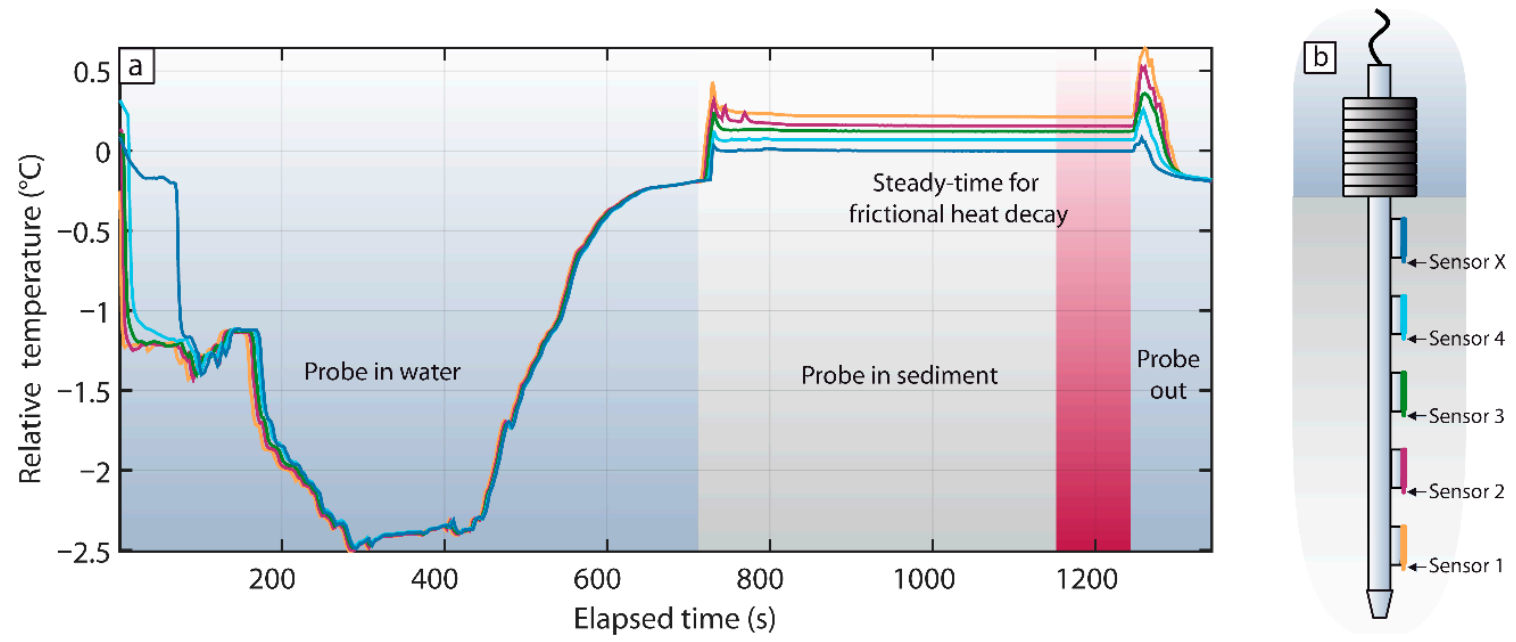

Figure 2. (a) The different deployment stages are highlighted for a data example. The probe is lowered through the water column; frictional heat is created when the instrument enters the sediment. The steady-time allows for frictional heat decay. During the stabilization phase, temperature signal variations become relatively small and only occur near the sensor resolution range $( \pm 0.001 \mathrm{~K})$. (b) Schematic drawing of the probe and sensor geometry. The sediment sensors are equidistantly mounted along the metal rod. The weight at the upper end enforces sediment penetration. A water sensor is fixed above the weight. Please note for simplification of this figure, they appear to be in line, whereas they were distributed around the rod to minimize the disturbance of the sediment. Measurements were conducted at 17 sites at the western Antarctic Peninsula Shelf, the South Orkney Shelf, and in the Powell Basin.

The thermal probe is lowered through the water column to the sea floor, where it enters the sediment by gravitational force due to its own weight (Figure 2a). Frictional heat is usually generated during this step, hence the probe is left in the sediment for up to 10 min, allowing in situ temperature to stabilize. An additional MTL was mounted above the probes weight to monitor the water column temperature (not shown in sketch). 
We measured the thermal conductivity $\mathrm{k}$ of sediment samples onboard. The samples were taken with a gravity corer at the heat flow stations or in their vicinity. The gravity corer whole rounds were stored up to $24 \mathrm{~h}$ at stable ambient temperatures prior to the analysis and the casing opened with a drill for the measurements. We used the KD2 Pro Thermal Property Analyzer that has an accuracy of $\pm 5 \%$ from 0.2 to $2 \mathrm{~W} \mathrm{~m}^{-1} \mathrm{~K}^{-1}$ [23]. The $6 \mathrm{~cm}$ length sensor is inserted into the sediment sample, applies a very small amount of heat to the needle, and calculates the thermal conductivity from heat dissipation.

The sampling strategy was determined to an extent by sea ice conditions, sedimentary cover thickness, water depth, and water column temperature stability. We were able to identify five suitable sites close to James Ross Island and the Antarctic Sound to measure in situ temperature measurements.

During RV Polarstern Expedition PS86 [20] to the Aurora Vent Field, geothermal heat flow observations were part of the multidisciplinary study of geophysical, geological, geochemical, and biological processes at the hydrothermal vents of the Arctic Gakkel Ridge. In situ sediment temperatures and geothermal heat flow were measured with a multithermistor "violin-bow" heat flow probe [24]. The sensor string is $6 \mathrm{~m}$ long and houses 21 thermistors with $1 \mathrm{mK}$ precision. Similar to the MTL deployments, the heat flow probe was lowered to the seabed and inserted into the sediment by its own weight. A first, frictional heat pulse is then generated (see Figure 3), after an up to 10 min stabilization time, during which the frictional heat of probe entry into the sediments dissipates and sediment temperatures may be considered to reflect undisturbed levels. A heat pulse is then triggered, and from the recording of the thermal decay curves thermal conductivities (k) and diffusivities can then be estimated [24,25].
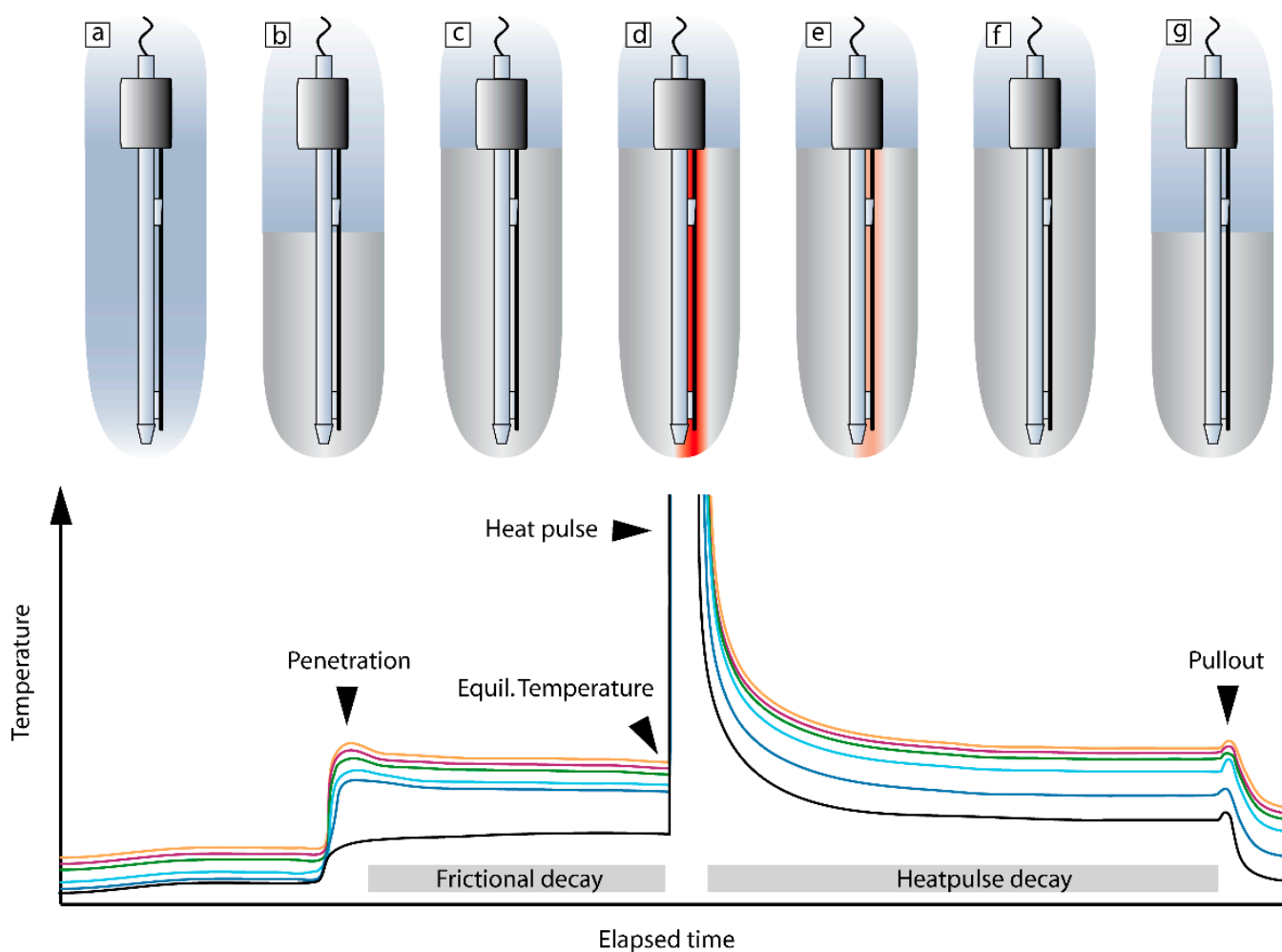

Figure 3. Temperature measurements and thermal conductivity estimate with a violin-bow heat flow probe. (a) Probe is lowered through the water column and (b) penetrates into the seabed, where frictional heat is generated. During the steady-time (c), the frictional heat dissipates, sediment temperatures equilibrate, and geothermal gradients are inferred from the sensor readings and the probe geometry. (d) A heat pulse rises sediment temperatures and from the recording of the thermal decay curve $(\mathbf{e}, \mathbf{f})$ thermal conductivities and diffusivities can be estimated. (g) Probe is pulled out of the sediment and retrieved back on board. The lower panel shows a typical temperature recording of six sensors exemplarily. Please note that the violin-bow configuration typically consists of a string with 21 sensors, but the lower graph shows only six sensor data curves. Sketch adapted and modified after [26]. 
The principle behind both measurement types for obtaining geothermal heat flow remains similar. The geothermal gradient describes the rate of temperature increase with increasing depth. From the known sensor geometry and temperature readings, this gradient can be estimated (Figure 4). The resulting heat flow $Q\left(\mathrm{mWm}^{-2}\right)$ has been formulated as an empirical relationship between the (negative) temperature gradient $d T / d z$ in the direction of energy flow and the physical property of a material to transport energy [27], the thermal conductivity $(k)$ :

$$
Q=-k \frac{\delta T}{\delta z}
$$

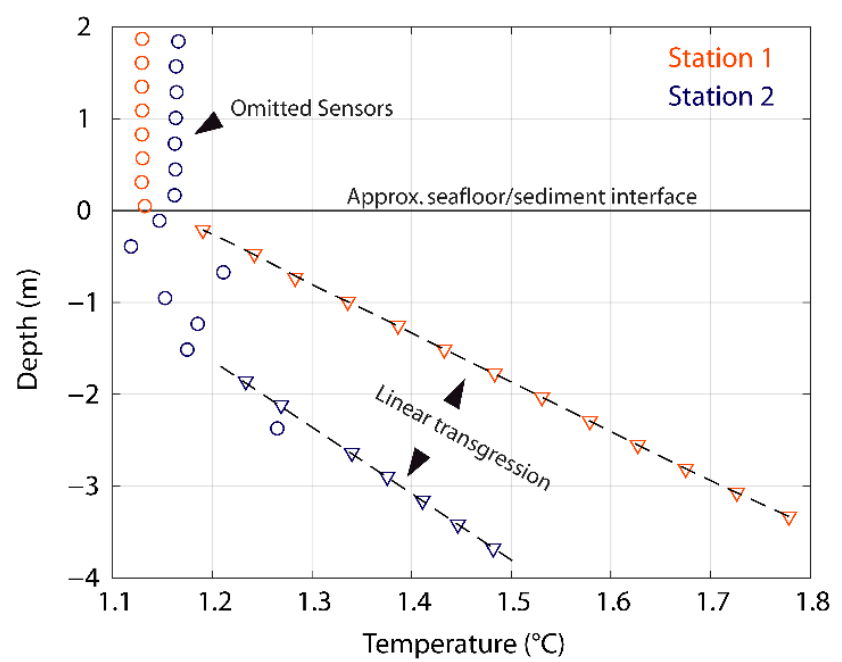

Figure 4. In situ temperature readings of the individual sensors with depth in the sediment for two example stations after the frictional heat decay. The temperature gradient is obtained from a linear transgression through the data points. Triangles mark sensor readings used for thermal gradient calculations and circles mark omitted sensors.

The figure demonstrates two cases for fictional stations. The temperature readings of station 1 represent a nearly ideal measurement, where the seafloor location can be approximated by the sudden gradient change. The sensor readings of the temperature in the sediment indicate stable conditions by a linear trend. In this case, all sensors can be used for calculating the temperature gradient. Station 2 shows a different example, where suspected thermal perturbations require certain sensors to be omitted (marked with circles) and not used for gradient estimation. Errors were estimated by calculating the minimum and maximum ranges of geothermal gradients, when temperature-depth readings showed ambiguous distributions.

\subsection{Depth-to-Bottom of the Magnetic Source (DBMS) in the Arctic Ocean}

When temperature increases with depth above the Curie temperature $\left(\sim 580{ }^{\circ} \mathrm{C}\right)$, ferromagnetic magnetization is lost [28]. The depth of this isotherm in the crust (the Curie point depth) is thus assumed to be the depth of the bottom of the magnetic source (DBMS) determined from magnetic survey data. The DBMS can be mapped based on magnetic anomaly spatial data and provides information of the thermal state of the lithosphere not accessible by other means [29]. Regions found to have a shallower DBMS (and thus an assumed shallower CPD) are expected to have higher average temperature gradients, and, therefore, higher GHF [30-32].

We apply the common spectral method [33,34] to the EMAG2 magnetic anomaly grid available for the Arctic ocean [35]. The prism-based method assumes that low wavenumber features in the power spectrum result from deepest magnetic sources (Figure 5). Top $\left(Z_{t}\right)$ and center $\left(Z_{0}\right)$ of the deepest magnetic body are then inferred from the slope of the power 
spectrum of the gridded magnetic anomalies and the bottom depth $\left(Z_{D B M S}\right)$ calculated from the geometric relationship of:

$$
Z_{\text {DBMS }}=2 Z_{0}-Z_{t} .
$$

Magnetic anomaly window

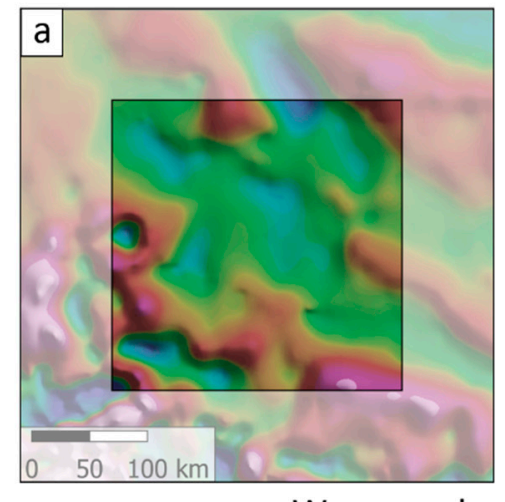

Wavenumber $\left(\mathrm{km}^{-1}\right) 0$

Wavelength $(\mathrm{km})$

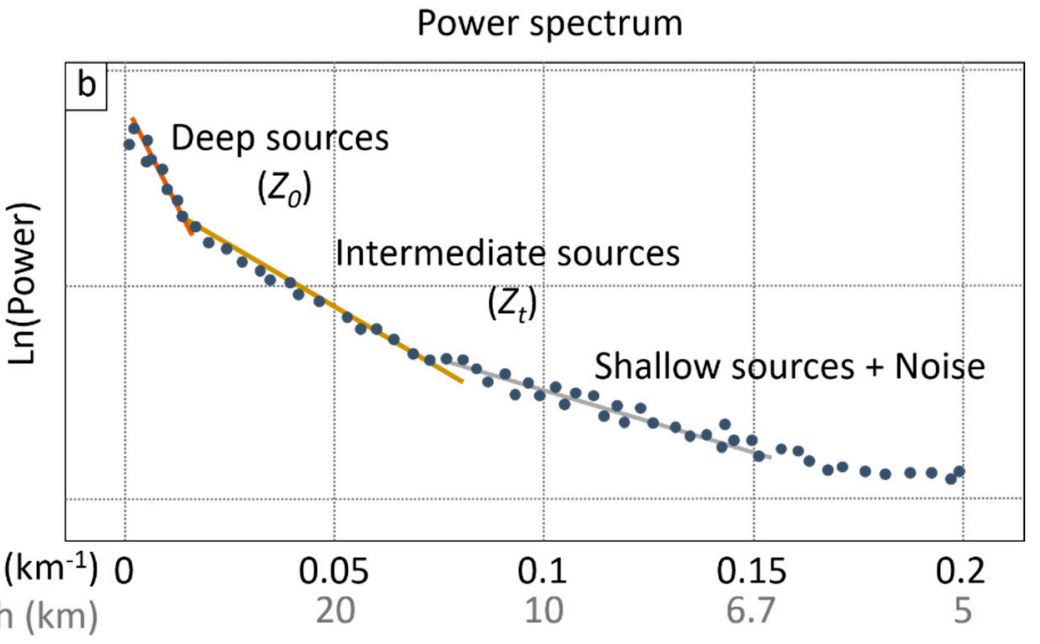

Figure 5. (a) Simplified sketch of the identification of the slopes of the intermediate and long wavelength magnetic anomalies from the power spectrum of magnetic anomalies within a single magnetic window (b). For illustration, small circular anomalies in the magnetic window (b) would correspond to shallow sources in the power spectrum, whilst larger anomalies would correspond to intermediate and deep sources.

The power spectra of magnetic anomalies are computed within overlapping (50\%) rectangular windows regularly spaced over the region of interest. The window size may, in some cases, need to be 10 times the DBMS, though larger window sizes may average tectonic regime detail. For the current study, we used a $200 \mathrm{~km} \times 200 \mathrm{~km}$ window.

\section{Results}

\subsection{Heat Flow across the Western Weddell Sea Shelf}

We present five marine temperature gradients in the western Weddell Sea across the continental shelf (see Figure 6 and Table 1), which are the first such measurements obtained from this remote area. The penetration depth of station HF1901 reached only $2 \mathrm{~m}$ into the sediment, which increases the error $\left( \pm 26 \mathrm{~mW} \mathrm{~m}^{-2}\right)$ for estimating geothermal heat flow, but is within the overall range of the stations in the current study. CTD measurements recorded a stable temperature profile from $350 \mathrm{mbsl}$ down to the sea floor at $450 \mathrm{mbsl}$. HF1902 was located at a water depth of $409 \mathrm{msbl}$ and MTL readings showed varying temperatures in the bottom water between -1.08 and $-1.6^{\circ} \mathrm{C}$, hence the upper meters of the sediment may contain a thermal overprint associated with changes in bottom water temperatures [36]. This effect in the upper sedimentary layers can also be seen in the temperature-depth profile obtained from station HF1903 at $415 \mathrm{msbl}$, which is located $1.9 \mathrm{~km}$ northwards of station HF1903. In general, only the measurements from depths greater than $4 \mathrm{mbsf}$ were used to estimate geothermal gradients and subsequently geothermal heat flow. Station HF1905 and HF1906 are $2.5 \mathrm{~km}$ apart and present a nearly linear temperature-depth profile of the sediments at water depths of 355 and $426 \mathrm{msbl}$, respectively. The estimated heat flow values for the individual stations, listed in Table 1, range from 75 to $130 \mathrm{~mW} \mathrm{~m}^{-2}$ and show a northward, decreasing trend towards the Powell Basin. 


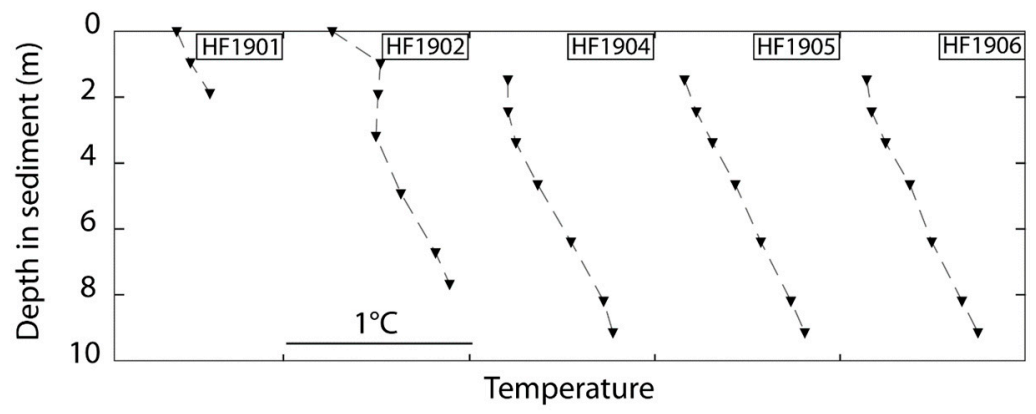

Figure 6. Temperature-depth profiles from five in situ measurements across the western Weddell Sea Shelf. Note the scale bar indicating a range of $1{ }^{\circ} \mathrm{C}$.

Table 1. Results of geothermal heat flow estimates from thermal measurements during RV Polarstern Expedition PS118 and PS86 (Supplementary Materials). Latitude and longitude are given in decimal degrees, thermal conductivity (k) for each station, the resulting geothermal heat flow (GHF). The GHF error estimate is based on minimum and maximum geothermal gradients and considerations of $\mathrm{k}$ for each station.

\begin{tabular}{|c|c|c|c|c|c|c|}
\hline Region & Station & $\begin{array}{c}\text { Latitude } \\
\text { (Decimal Degree) }\end{array}$ & $\begin{array}{c}\text { Longitude } \\
\text { (Decimal Degree) }\end{array}$ & $\mathrm{k}(\mathrm{W} / \mathrm{mK})$ & $\begin{array}{c}\text { GHF } \\
\left(\mathrm{mW} / \mathrm{m}^{2}\right)\end{array}$ & $\begin{array}{c}\text { Error } \\
\left(\mathrm{mW} / \mathrm{m}^{2}\right)\end{array}$ \\
\hline \multicolumn{7}{|c|}{ Antarctica } \\
\hline Weddell Sea Shelf ${ }^{1}$ & HF1901 & -64.9855 & -57.7694 & 1.33 & 139 & 26 \\
\hline Weddell Sea Shelf ${ }^{1}$ & HF1902 & -64.0627 & -56.1563 & 1.33 & 125 & 5 \\
\hline Weddell Sea Shelf 1 & HF1903 & -64.0497 & -56.1361 & 1.33 & 126 & 3 \\
\hline Powell Basin 1 & HF1904 & -62.3226 & -51.6758 & 1.05 & 86 & 0 \\
\hline Weddell Sea Shelf ${ }^{1}$ & HF1905 & -63.0627 & -54.3495 & 0.86 & 75 & 5 \\
\hline Weddell Sea Shelf ${ }^{1}$ & HF1906 & -63.0812 & -54.3276 & 0.86 & 78 & 10 \\
\hline South Orkney Shelf 1 & HF1908 & -60.9289 & -46.5618 & 0.66 & 41 & 1 \\
\hline Powell Basin ${ }^{1}$ & HF1909 & -61.1236 & -47.7338 & 0.95 & 69 & 6 \\
\hline Powell Basin ${ }^{1}$ & HF1910 & -61.1239 & -48.2835 & 0.86 & 74 & 8 \\
\hline Powell Basin ${ }^{1}$ & HF1911 & -61.1224 & -48.9201 & 1.05 & 16 & 4 \\
\hline Powell Basin ${ }^{1}$ & HF1912 & -61.1683 & -49.7056 & 0.96 & 71 & 6 \\
\hline Powell Basin ${ }^{1}$ & HF1914 & -60.8382 & -49.8366 & 0.96 & 55 & 0 \\
\hline Powell Basin ${ }^{1}$ & HF1915 & -60.8523 & -49.6517 & 0.96 & 56 & 0 \\
\hline Powell Basin ${ }^{1}$ & HF1916 & -60.8477 & -49.3972 & 1.43 & 34 & 6 \\
\hline Powell Basin ${ }^{1}$ & HF1917 & -60.8476 & -48.5034 & 1.33 & 47 & 20 \\
\hline Powell Basin ${ }^{1}$ & HF1918 & -60.8350 & -48.2141 & 0.95 & 55 & 6 \\
\hline Powell Basin 1 & HF1919 & -60.8467 & -47.6762 & 1.20 & 65 & 3.6 \\
\hline \multicolumn{7}{|c|}{ Arctic Ocean } \\
\hline Aurora Vent Field 2,3 & H1401P01 & 82.9227 & -6.2049 & 1.32 & 1825 & 259 \\
\hline Aurora Vent Field ${ }^{2}$ & $\mathrm{H} 1401 \mathrm{P} 02$ & 82.9219 & -6.1959 & 1 & 743 & 103 \\
\hline Aurora Vent Field ${ }^{2}$ & H1401P03 & 82.9194 & -6.1667 & 1 & 39 & 5 \\
\hline Aurora Vent Field 2,3 & H1401P04 & 82.9184 & -6.1510 & 1.14 & 749 & 108 \\
\hline Aurora Vent Field 2,3 & H1402P01 & 82.9083 & -6.2292 & 1.06 & 199 & 0.4 \\
\hline Aurora Vent Field ${ }^{2}$ & $\mathrm{H} 1402 \mathrm{P} 02$ & 82.9072 & -6.2389 & 1 & 177 & 0 \\
\hline Aurora Vent Field ${ }^{2}$ & H1402P03 & 82.9059 & -6.2362 & 1 & 144 & 4 \\
\hline Aurora Vent Field 2,3 & H1403P01 & 82.8894 & -6.2218 & 1.04 & 14 & 6 \\
\hline Aurora Vent Field ${ }^{2}$ & H1403P02 & 82.8881 & -6.2240 & 1 & 70 & 4 \\
\hline Aurora Vent Field ${ }^{2}$ & Н1403Р03 & 82.8889 & -6.2139 & 1 & 11 & 1 \\
\hline Aurora Vent Field ${ }^{2}$ & H1403P04 & 82.8886 & -6.2022 & 1 & 8 & 0 \\
\hline Aurora Vent Field 2,3 & H1403P05 & 82.8875 & -6.1878 & 1.09 & 19 & 3 \\
\hline Aurora Vent Field 2,3 & H1404P01 & 82.9060 & -6.2675 & 1.06 & 133 & 5 \\
\hline Aurora Vent Field 2,3 & $\mathrm{H} 1404 \mathrm{P} 02$ & 82.9013 & -6.2317 & 1.09 & 136 & 5 \\
\hline Aurora Vent Field ${ }^{2}$ & $\mathrm{H} 1404 \mathrm{P} 03$ & 82.9013 & -6.2085 & 1 & 47 & 2 \\
\hline Aurora Vent Field ${ }^{2}$ & H1404P04 & 82.9021 & -6.1929 & 1 & 18 & 2 \\
\hline Aurora Vent Field 2,3 & H1405P01 & 83.1094 & -5.7635 & 1.16 & 224 & 10 \\
\hline Aurora Vent Field 2 & $\mathrm{H} 1405 \mathrm{P} 02$ & 83.1050 & -5.7698 & 1.16 & 10 & 2 \\
\hline Aurora Vent Field 2,3 & H1406Р01 & 82.9036 & -6.5432 & 1.12 & 371 & 5 \\
\hline
\end{tabular}


Table 1. Cont.

\begin{tabular}{|c|c|c|c|c|c|c|}
\hline Region & Station & $\begin{array}{c}\text { Latitude } \\
\text { (Decimal Degree) }\end{array}$ & $\begin{array}{c}\text { Longitude } \\
\text { (Decimal Degree) }\end{array}$ & k (W/mK) & $\begin{array}{c}\text { GHF } \\
\left(\mathrm{mW} / \mathrm{m}^{2}\right)\end{array}$ & $\begin{array}{c}\text { Error } \\
\left(\mathrm{mW} / \mathrm{m}^{2}\right)\end{array}$ \\
\hline Aurora Vent Field ${ }^{2,3}$ & H1406P02 & 82.9013 & -6.5428 & 1.16 & 545 & 8 \\
\hline Aurora Vent Field 2,3 & H1406P03 & 82.8986 & -6.5391 & 1.05 & 395 & 0.5 \\
\hline Aurora Vent Field 2,3 & H1407P01 & 82.9275 & -6.3564 & 1.18 & 131 & 2 \\
\hline Aurora Vent Field ${ }^{2}$ & H1407P02 & 82.9238 & -6.3975 & 1.16 & 230 & 7 \\
\hline Aurora Vent Field ${ }^{2}$ & H1407P03 & 82.9226 & -6.4255 & 1.16 & 301 & 5 \\
\hline Aurora Vent Field ${ }^{2}$ & H1407P04 & 82.9209 & -6.4711 & 1.16 & 455 & 0 \\
\hline Aurora Vent Field 2,3 & H1408P01 & 83.1114 & -2.4656 & 1.30 & 32 & 0 \\
\hline Aurora Vent Field 2,3 & H1408P02 & 83.1099 & -2.4490 & 1.33 & - & - \\
\hline
\end{tabular}

${ }^{1}$ Miniaturized temperature data-logger, ${ }^{2}$ heat flow probe, ${ }^{3}$ heat pulse.

\subsection{Heat Flow across the Powell Basin}

Two transects (HF1908-HF1919) and a reference site (HF1904) were measured within the Powell Basin, aiming to cover the different crustal regimes. The northern transect with temperature-depth profiles and corresponding bathymetric profile is shown in Figure 7. On the flanks of the basin, the sedimentary cover did not support probe penetration. The sedimentary cover on the central rise was thin and coarse. Furthermore, Parasound data indicated coral-like structures, which typically require a hard substrate to settle on. Therefore, we were not able to retrieve measurements on the bathymetric high. Estimates of geothermal heat flow range from 16 to $86 \mathrm{~mW} \mathrm{~m}^{-2}$. Highest penetration depths of the temperature probe were achieved in sedimentary basins on either side of the bathymetric high. At site HF1917, the influence of changing bottom waters can be traced in the upper sediment temperatures. Due to lower penetration depth and a non-linear temperature gradient in the upper sedimentary layers, the estimated error of this station is $\pm 26 \mathrm{~mW} \mathrm{~m}^{-2}$. The upper two sensors of site HF1919 recorded a contrary trend and a reversal in temperature gradients within the upper two meters below seafloor and were also not included in the geothermal heat flow estimates.

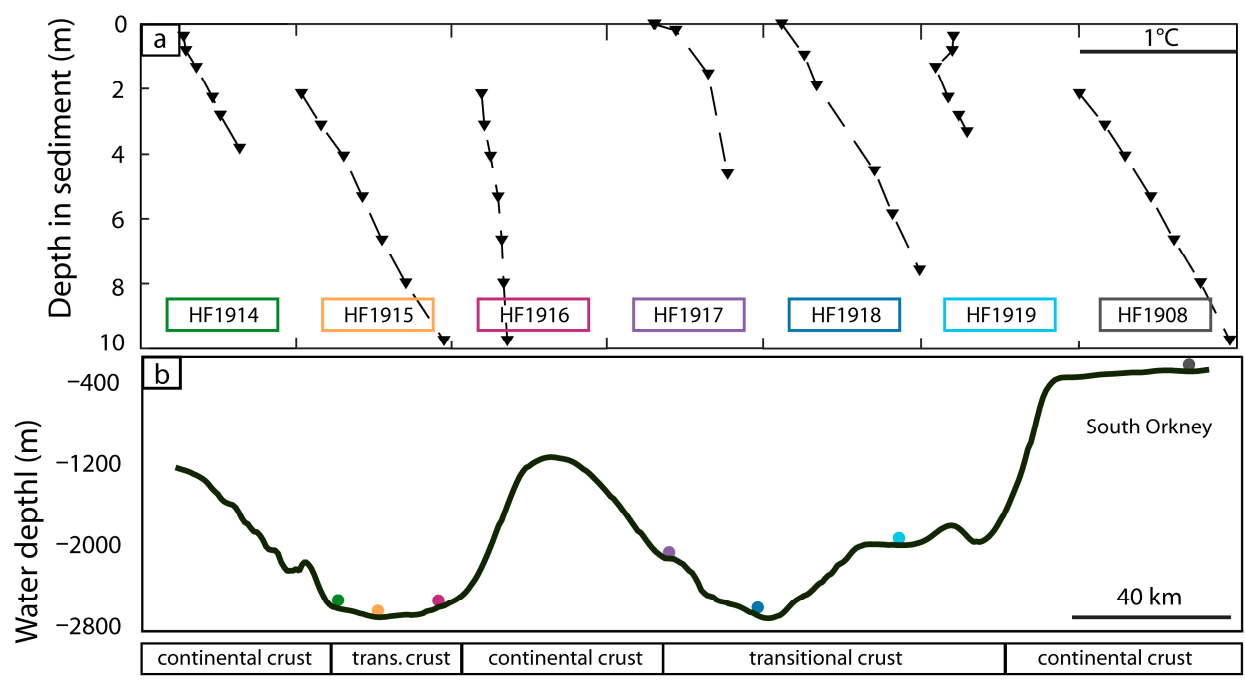

Figure 7. (a) Northern temperature-depth Profile 1 across the Powell Basin. (b) Location of the sea floor with reference to sea level and stations of the individual in situ temperature measurements indicated by colored circles. Crustal segments after [37].

\subsection{Heat Flow Along the Gakkel Ridge}

Geothermal heat flow was investigated at 27 sites in the Western Volcanic Zone of the Gakkel Ridge with the violin-bow type heat flow probe (Figure 1, Table 1). At selected stations, a heat pulse was triggered to estimate in situ thermal conductivity. Highest geothermal gradients were obtained at Station H1401P01, -P02, and P04, with observed geothermal heat flow ranges between $734 \pm 103 \mathrm{~mW} \mathrm{~m}^{-2}$ and $1825 \pm 259 \mathrm{~mW} \mathrm{~m}^{-2}$. The large error 
estimates result from gradient variations, penetration depths, and thermal conductivity changes. A pronounced temperature anomaly seems to run through depths of 3 to $4 \mathrm{mbsf}$ in the area of the HF1401 sites (see Figure 8). The temperature-depth profile of station H1401P01 does not show a strong lateral variation, which might be due to the shallow penetration depth.

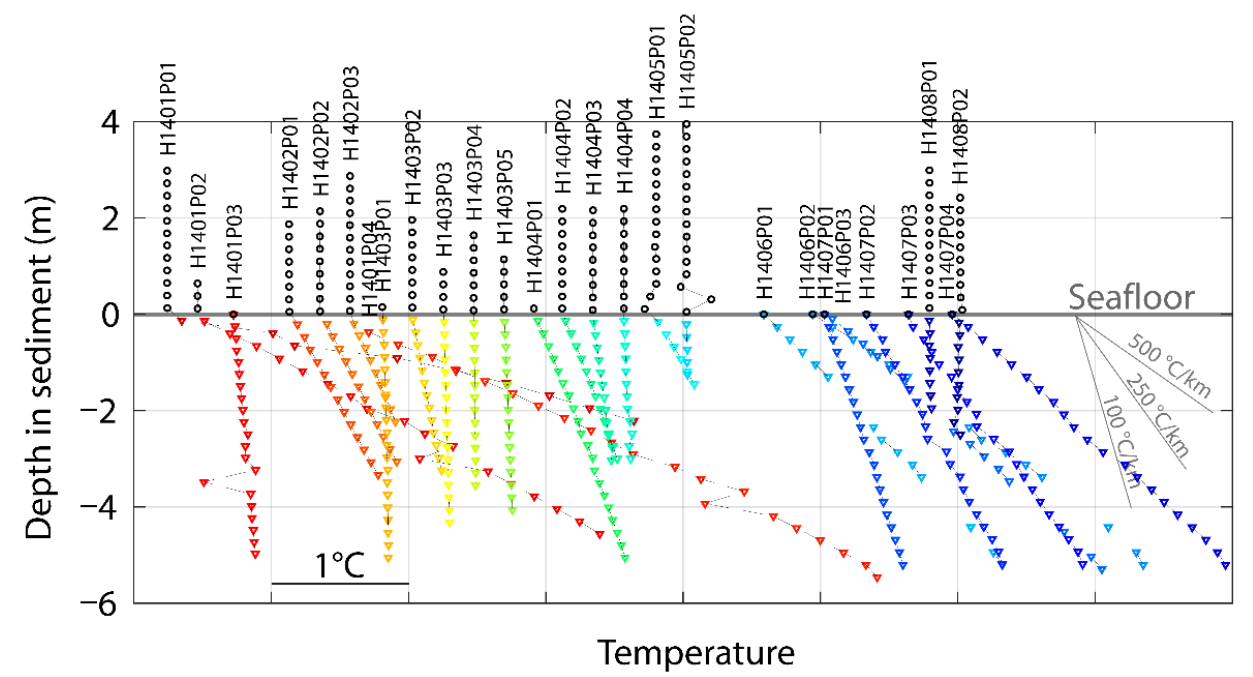

Figure 8. Relative temperature-depth profiles of the thermal investigations during RV Polarstern expedition PS86. Colored triangles indicate sensors that have entered the sediment. Black circles mark sensor readings in the water column above the inferred seafloor location $(0 \mathrm{~m})$. All profiles are shown in one figure for inter-comparability. Please note the scale of $1^{\circ} \mathrm{C}$.

Stations H1402P01-P03 generally show linear temperature gradients, which are indicative for thermally stable conditions. At sites H1403P01, -03P04, -04P03, -04P04, -05P02, $-08 \mathrm{P} 01$, and $-08 \mathrm{P} 02$ gradients showed intermediate to strong thermal perturbations, resulting in high uncertainties for the GHF estimate, besides the given error range. The sampling strategy was biased towards areas with a sedimentary cover sufficiently thick to allow for sufficient heat flow probe penetration.

\section{Discussion}

\subsection{Weddell Sea and Antarctic Peninsula}

The presented marine in situ temperature measurements HF1901 to HF1906 across the shelf are the first observations of their kind in the wide western Weddell Sea of the southern polar region.

The geothermal heat flow estimates show a decreasing trend from south of James Ross Island (HF1901: $139 \pm 26 \mathrm{~mW} \mathrm{~m}^{-2}$ ) towards northeast of the Peninsula (HF1906: $78 \pm 10 \mathrm{~mW} \mathrm{~m}^{-2}$ ). The only in situ temperature measurement in the vicinity of the current study stations is from a $363.9 \mathrm{~m}$ deep ice-borehole near the summit of Mount Haddington on James Ross Island, at an elevation of $1542 \mathrm{~m}$ drilled to the bedrock in 2008 [9]. The study found the basal temperature of the ice sheet $\left(-8.5^{\circ} \mathrm{C}\right)$ measured in the borehole to be consistent with a geothermal heat flow of around $50 \mathrm{~mW} \mathrm{~m}^{-2}$ at the location. However, little detail is given about the heat flow estimate in the study.

The oceanic and continental heat flow average is 101 and $65 \mathrm{mWm}^{-2}$, respectively [38]. Hence, indirect models, for instance, models $\left(67 \mathrm{mWm}^{-2}\right)$ from heat producing elements (HPEs) assigned to bedrock geology [39] (Figure 9a) and the borehole estimate $\left(50 \mathrm{mWm}^{-2}\right)$ of geothermal heat flow, fall in the lower predicted range of geothermal heat flow. Magnetically-derived geothermal heat flow models [12] predict a range of 70 to $100 \mathrm{~mW} \mathrm{~m}^{-2}$ for the region and show a decreasing trend from higher values south of James Ross Island towards lower values in the northeast (Figure 9b), these results fit well with our observations. In contrast, empirical, seismically-derived models $[11,13]$ largely 
agree with each other (Figure 9c,d), but predict a reversed northerly trend from lower heat flow towards higher geothermal heat flow values. Whereas this trend is largely consistent with marine in situ data collected in the Bransfield Strait $[40,41]$, it shows a large offset of $\sim 40$ to $\sim 70 \mathrm{~mW} \mathrm{~m}^{-2}$ for the Powell Basin region. Our results (75 to $139 \mathrm{mWm}^{-2}$ ) therefore are indicative of a considerably higher geothermal heat flow and are mainly consistent with the seismically-derived models with respect of absolute values, but in terms of local trends, correlate more with magnetically-derived models.
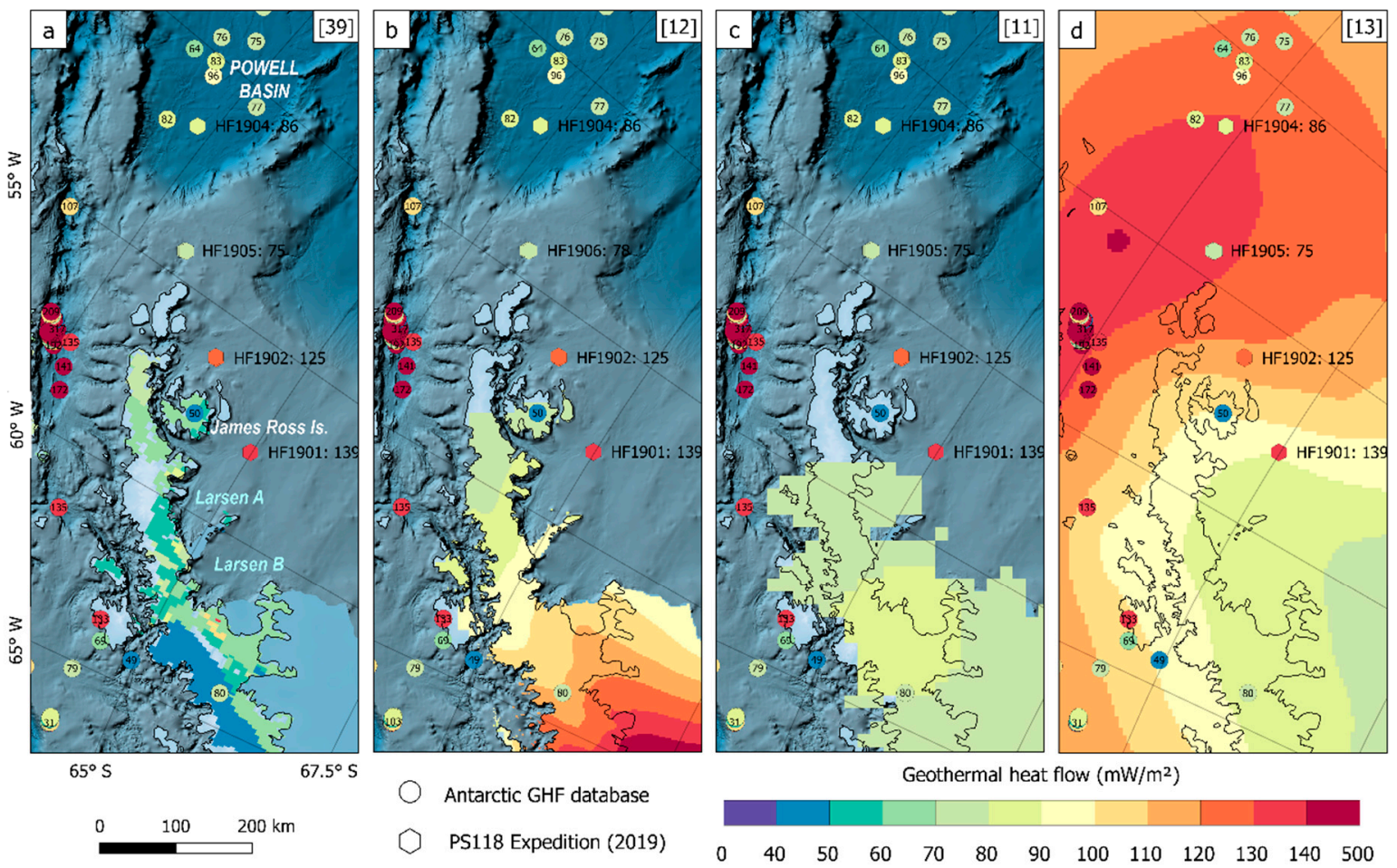

Figure 9. (a) GHF model derived from heterogeneous crustal heat production [39]. (b) Magnetically-derived GHF model [12]. (c,d) Seismically-derived GHF models [11,13]. In situ data from the Antarctic Geothermal Heat Flow database [42] marked with color-coded circles. In situ measurements from this study marked with color-coded hexagons. Bathymetric map from shows bed elevation from BedMachine Antarctica [6].

The explanation of high geothermal heat flow around James Ross Island remains subject to speculation. The thermal signature could be part of a wider regional trend indicative of a generally high geothermal heat flow across the Antarctic Peninsula. This could be a result from dynamic mantle processes related to ongoing subduction, given the late Paleozoic and viscous coupling of the back-arc with the subducting slab. Of further significance would be the tectonic and magmatic history, such as the emplacement of plutonic rocks and volcanic intrusions, which typically inherit high thermal conductivities. The thermal gradients of such a back-arc region are generally elevated [43]. Extensive Upper Jurassic to lower tertiary clastic sediments and tuff [44] could have additionally resulted in the accumulation of HPEs, which contribute significantly to geothermal heat flow.

Understanding the thermal signature of the crust and mantle in the region of the Antarctic Peninsula has important implications for ice-sheet models. The ice mass balance is negative and ice mass loss one of the highest in all of Antarctica [45]. Rapid changes in climate over the past decades have led to the collapse of major ice shelves, such as Larsen A in 1995 and Larsen B in 2002 [46,47]. As a response to ice unloading, the region experiences a rapid bedrock uplift [48]. A clue towards understanding the long-term evolution of the ice sheets in the region is associated with the visco-elastic behavior of the crust, which is coupled to temperature. The discrepancies and ambiguities of the different models heat flow predictions for the Antarctic Peninsula are amongst the highest $\left(>50 \mathrm{mWm}^{-2}\right)$ in all 
of Antarctica [42]. Our findings support an elevated heat flow, which is consistent with the mean of the most common indirect studies presented in [42]. However, further in situ temperature constraints, for instance, from borehole campaigns that reach the bedrock below the ice sheet, are urgently required to ground-truth existing models and validate these hypotheses.

\subsection{Powell Basin}

The Powell Basin is a small oceanic basin bounded by continental blocks that fragmented during drifting of South America away from Antarctica [49]. The timing of its opening is poorly constrained due to low amplitude magnetic anomalies and proposed ages in the Late Eocene to Late Miocene vary from 32 to $18 \mathrm{Ma}$ ([37] and references therein). The basin is bound by the South Scotia Ridge, which is a complex system of structural highs, small basins, and narrow depressions [37]. The western and eastern margins are conjugate passive margins with a transitional crust in the continent-ocean boundary (Figure 10). The eastern margin represents the overplate, and it also shows significant faulting which seems to be active until recently [50]. Towards the north and south, the basin is characterized by a transcurrent margin.

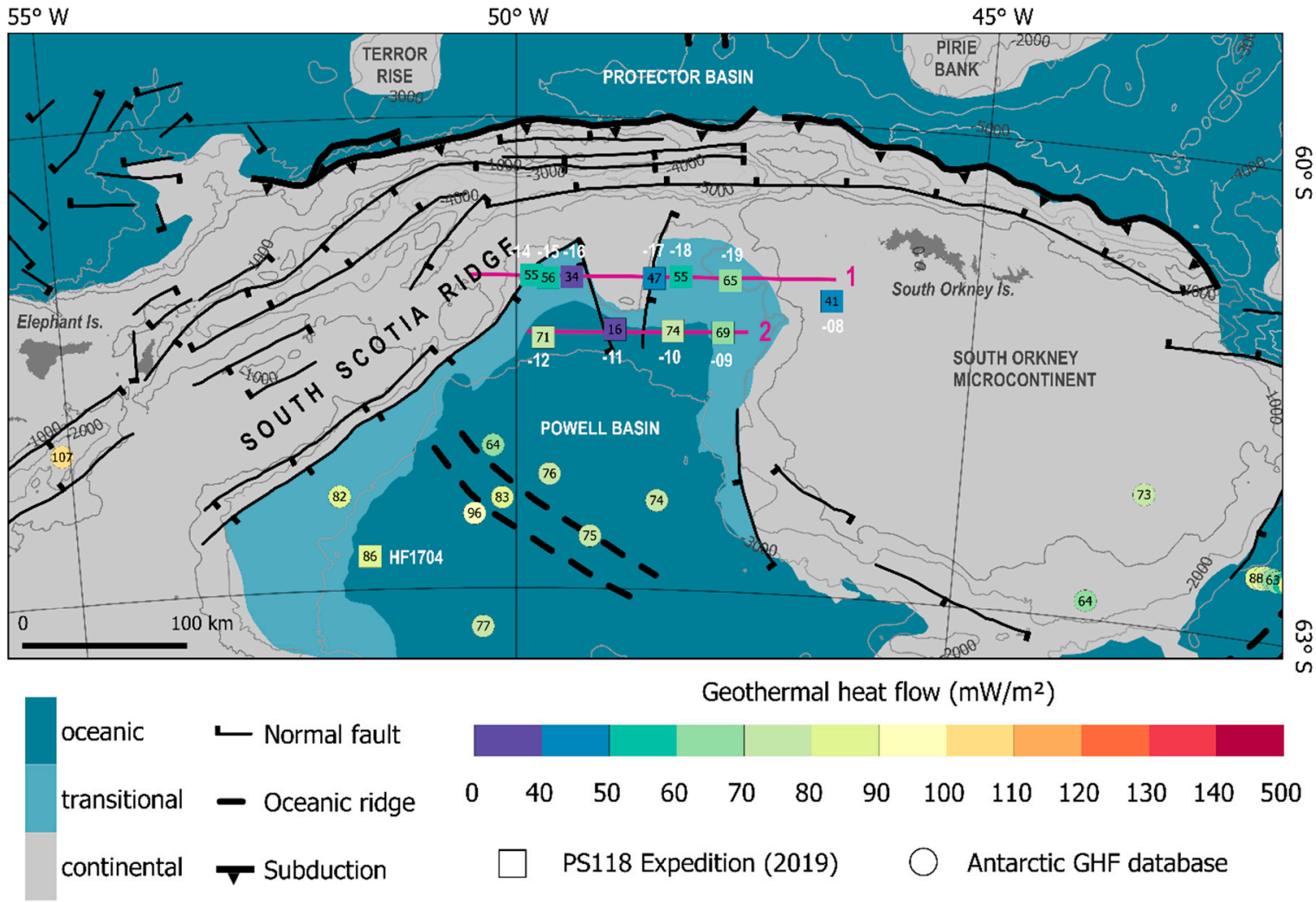

Figure 10. Major tectonic features and geothermal heat flow estimates of the Powell Basin region. HF19xx Profiles 1 and 2 indicated in magenta. Contour lines extracted from bed elevation of BedMachine Antarctica [6] at a $1000 \mathrm{~m}$ interval. Tectonic map adapted from [37].

The highest geothermal heat flow value of $96 \mathrm{~mW} \mathrm{~m}^{-2}$ in the Powell Basin nearly overlies a basement high, which might represent an extinct spreading center [51]. At Station HF1910 to HF1912 along Profile 2 that superpose the oceanic crustal segment, heat flow estimates are 74 and $71 \mathrm{~mW} \mathrm{~m}^{-2}$, respectively (Figure 10). At station HF1911, close to a normal fault confining the basement high, a low heat flow of $16 \mathrm{~mW} \mathrm{~m}^{-2}$ was calculated. The probe penetration at these stations was overall very good, with sensor depths in the sediment at $\sim 9.7$ mbsf. Profile 1 covers the transitional and continental crustal part and 
shows low to normal heat flow. The lowest values are found close to the normal faults and on the continental shelf of the South Orkney micro-continental block.

Faults present pathways for fluid migration, which could lead to localized distorted signatures in the thermal gradient. Submarine landslides, that typically occur at submarine slopes, can also serve as an explanation for non-linear temperature gradients as in e.g., HF1919 as the temperature-depth profile shows an abrupt change in a depth of 2 mbsf. The relocation of sediment from a different thermal regime to the site could cause such a thermal gradient distortion.

Around the bathymetric high, deposits from the entry of the Weddell Gyre into the semi-enclosed Powell Basin might have an influence on sedimentation and internal temperature gradients.

Sediments, in general, are deposited at the bottom-water temperature, depressing the geothermal gradient and in turn the heat flow [52]. Initially the effect of sedimentation on geothermal heat flow is negligible, but grows with time [52]. The ongoing sedimentation in the Powell Basin is non-linear as a result of glaciation cycles, on average up to $100 \mathrm{mMa}^{-1}$, and built sedimentary cover with a thickness of $\sim 2300 \mathrm{~m}$ [53]. Age models place the oldest sediments in the late Oligocene at 24.3 Ma. At these high sedimentation rates, geothermal heat flow is likely reduced by $\sim 10 \%$ at $10 \mathrm{Ma}$ [52], which would, for instance, result in a maximum reduction of $18 \mathrm{~mW} \mathrm{~m}^{-2}$ at Station HF1910. Such an elevated geothermal heat flow $\left(92 \mathrm{~mW} \mathrm{~m}^{-2}\right)$ is anomalous, yet consistent with a recently proposed heat flow model based on magnetic data [54]. A high-density channel characterized by high heat flow described in the study could not be verified by the presented data set, due to the data gaps and difficult measuring environment, such as hard substrate on top of the bathymetric high as the center region of channel. On comparison with global models [55], the presented heat flow values in the oceanic crustal domain fall in the predicted, normal range (see Figure 11).
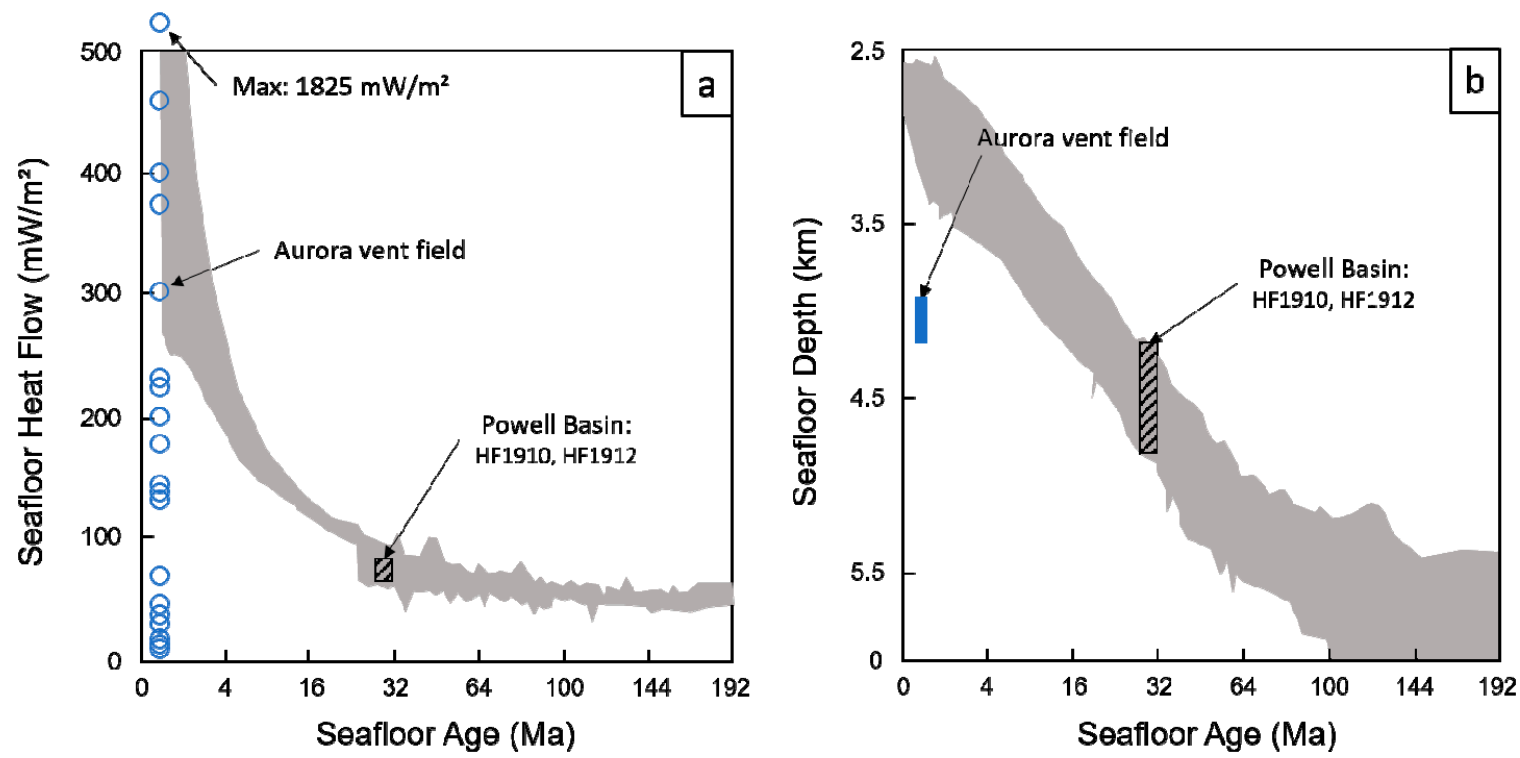

Figure 11. (a) Seafloor age versus seafloor heat flow from several models presented in [55] are shaded in grey. Black stripefilled box marks where HF1910 and HF1912 approximately fall into range. Blue circles mark a selection of geothermal heat flow estimates obtain at the Aurora Vent Field. (b) Seafloor depth versus seafloor age from [55]. After reduction of the sedimentary cover (1500-2300 m) approximated ages and depths at station HF1910 ( 2900 mbsl) and HF1912 (2780 mbsl) show a normal distribution. The Aurora Vent Field along the ultra-slow spreading Gakkel Ridge is located below predicted water depths for models of seafloor age versus depth. 


\subsection{Aurora Vent Field and Western Gakkel Ridge}

The Gakkel Ridge located in the Arctic Ocean separates the Amundsen and Nansen Basin and stretches $1800 \mathrm{~km}$ from the continental margin of the Laptev Sea in the east towards the Fram Strait in the west, where the plate boundary passes through Lena trough into the Knipovich ridge (see Figure 1c,d) [7]. The Gakkel Ridge has been characterized as the northern-most ultra-slow (less than $20 \mathrm{~mm} \mathrm{yr}^{-1}$ full rate) ocean ridge [56,57]. Asymmetric spreading, with higher rates towards the south, vary from $14.6 \mathrm{~mm} \mathrm{yr}^{-1}$ (full rates) in the western part to $6.3 \mathrm{~mm} \mathrm{yr}^{-1}$ in the Laptev Sea [57,58], thus the Gakkel Ridge spreads more slowly than any other mid-ocean ridge. Studies at (ultra-) slow spreading ridges have found significantly more volcanism and hydrothermal venting than expected, unique amagmatic segments along the ridge (SMZ, Figure $12 b)$, and thin seismic crust between approximately 1 and $4 \mathrm{~km}[7,57,59]$.
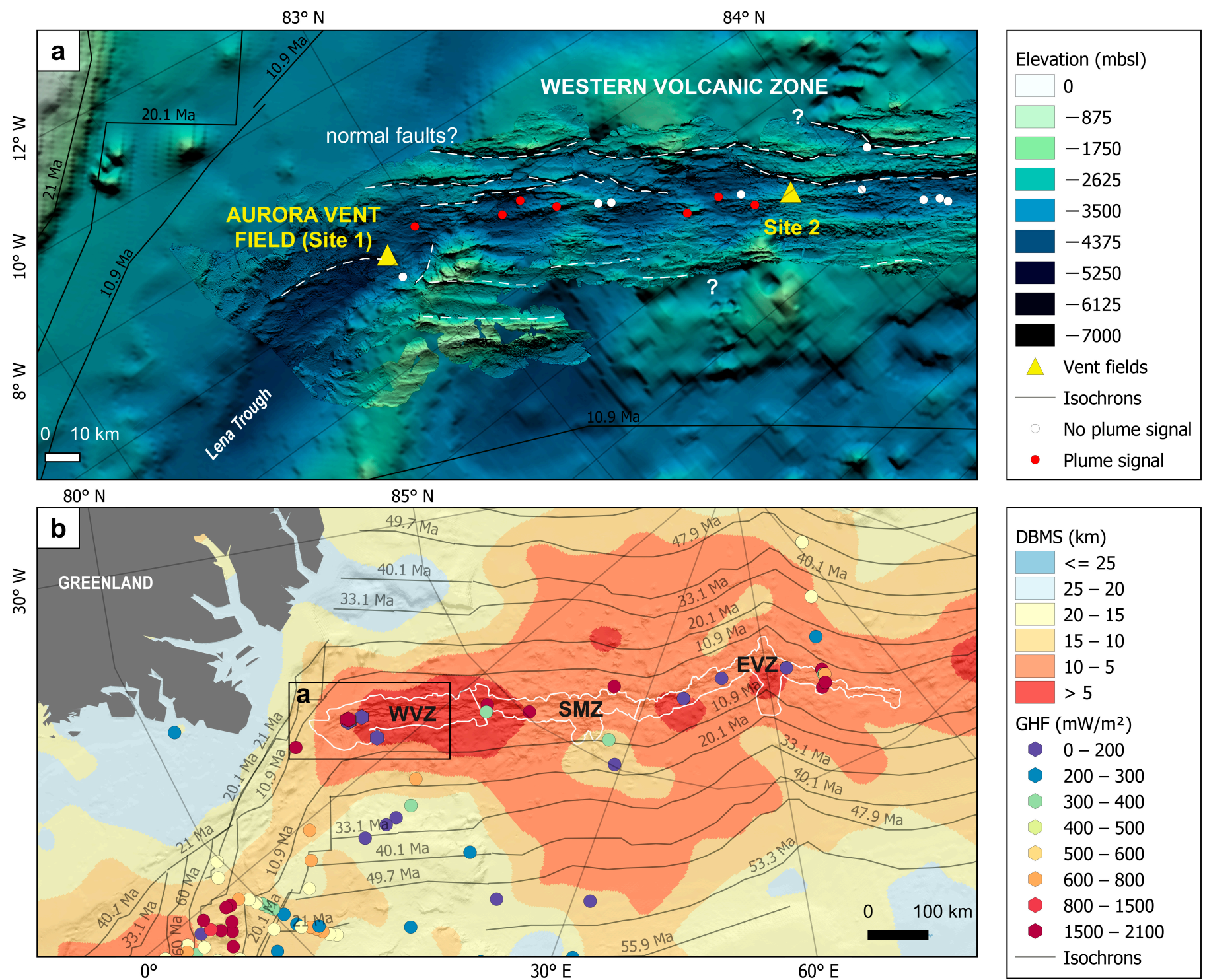

Figure 12. (a) Bathymetric map of the Western Volcanic Zone (WVZ) of the Gakkel Ridge. Aurora Volcanic Vent Field [21] located in the ridge center towards Lena Trough. Oceanic crustal ages from [60], water column plume signatures from [21] and vent fields from [61]. Dashed white lines indicate assumed locations of detachment faults. (b) Larger overview of the Gakkel Ridge and the Western Volcanic Zone (WVZ), Sparsely Magmatic Zone (SMZ), and Eastern Volcanic Zone (EVZ) after [7]. The depth-to-the-bottom of the magnetic source (DBMS) is based on EMAG2 [35]. Color-coded circles mark geothermal heat flow (GHF) sites from [62] and this study (PS86). Small inlet map shows extents of panel (a). 
The Aurora Vent Field is located in the Western Volcanic Zone (WVZ Figure 12), where strong magnetic anomalies and dredged basalts indicate a high robust melt production in the mantle [63]. Further to the east, the Eastern Volcanic Zone likewise only yielded basalt on dredgings, but volcanism occurs in isolated volcanic centers when compared to extended axial volcanic ridge systems in the Western Volcanic Zone. The Sparsely Magmatic Zone exposes mantle rocks at the seafloor and magmatic activity occurs only in few locations. The WVZ shows extended areas of shallow $(<5 \mathrm{~km})$ DBMS, whereas the EVZ exhibits more patchy locations of shallow DBMS. The amagmatic SMZ in contrast shows a wider distribution of increased magnetic crustal thickness $(5-10 \mathrm{~km})$. The area of shallow DBMS in the WVZ extends well into the SMZ across the sharp bathymetric boundary around $3^{\circ}$ east which separates both segments over short distances. We assume that this overlap is due to the spatial sampling of $200 \mathrm{~km} \times 200 \mathrm{~km}$, preventing sharp boundaries to be resolved accurately.

As the DBMS maps the thickness of the magnetized crust and hence the depth of the Curie temperature, it serves as a proxy for geothermal heat flow. Although studies have usually confirmed high GHF in regions of shallow DBMS (e.g., [31,64]), some uncertainty surrounds the method. The Curie temperature of $580^{\circ} \mathrm{C}$ neglects the compositional variety of different mineralogical assemblages, but remains the best approach, without further validation. Further, the effects of serpentinization of the upper mantle have been discussed, as potentially influencing the magnetic signal [65] and the importance of this impact on DBMS estimates remains unknown. However, investigations at the ultraslow spreading Southwest Indian Ridge found that basalt is the main carrier of magnetization and serpentinized peridotites do not contribute significantly to the magnetic anomaly pattern along that ridge, at least [66].

Therefore, our DBMS estimates serve as a general guide map for geothermal heat flow in the region and is largely consistent with the global DBMS models [32]. The localized areas of high geothermal gradients, as indicated by shallow DBMS, are consistent with comprehensive models of young oceanic crust [55]. The few existing in situ thermal estimates show elevated values of heat flow in the EVZ [67] compared to considerably lower values for same crustal age at the eastern margin of the SMZ. Along the axis in young ocean crust, a considerable variety in heat flow estimates was found (Figure 11a), with many values below expected heat flow values for zero age crust. This could be interpreted in terms of low heat production, but regional variability due to hydrothermal circulation and variability in crustal composition contributes to this complexity.

The recently proposed mechanisms of high-temperature hydrothermal circulation at the Southwest Indian Ridge could serve as an analogue for the processes behind Aurora Vent Field [68]. Hydrothermal circulations beneath vents or along faults can locally distort thermal gradients and lead to extreme variations of geothermal heat flow distribution at the seafloor.

Estimates of geothermal heat flow at the vent field presented in this study show a wide range characteristic for effects of hydrothermal circulation (Table 1, Figure 13). High geothermal heat flow is found north of the volcanic mount, whereas the vent field region is characterized by low heat flow estimates, which could be a bias due to the sampling strategy, since the presented in situ temperature measurements require a sedimentary cover. Stations, where low or reversed heat flow (H1408) was detected, also indicate thermally unstable conditions of the sediment. These could be a result of charging zones, where colder seawater enters the seafloor and potentially circulated to lower depths in the crust. 


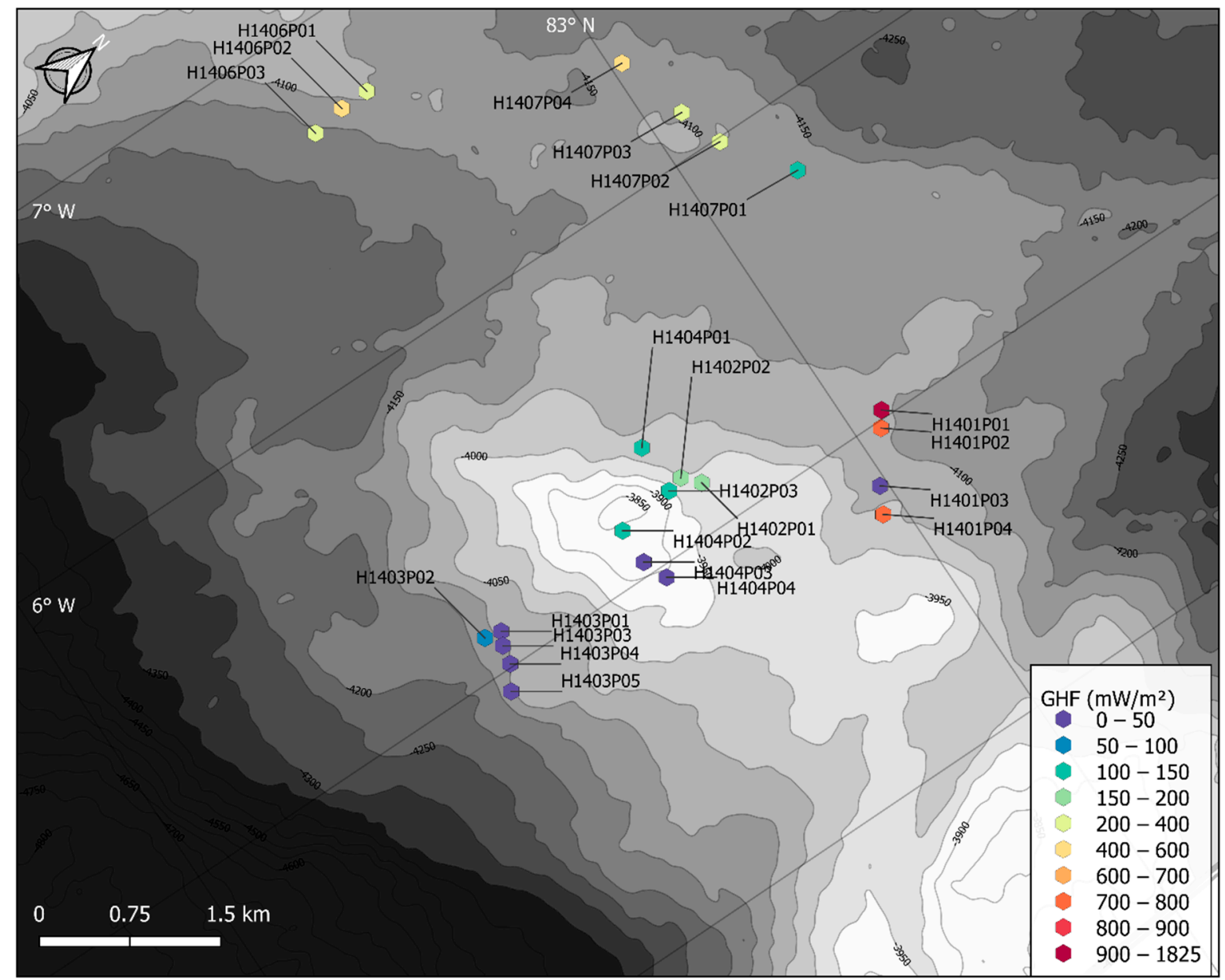

Figure 13. Close up of the Aurora Vent Field region shown in Figure 12. Geothermal heat flow sites (Table 1) are strongly heterogeneous over a small area, which is characteristic for hydrothermal ventilation.

Our results (ensembles: H1401, -06, -07) indicate that a heat source might not be located directly beneath the mount but with distance from it towards the rift center in the north and west. Near visually identified discharge areas, we find areas with comparably lower heat flow (ensembles: H1403, -04), which could be indicative for a nearby recharge area, where colder seawater might enter the sub-seafloor. Studies from fast spreading ridges [69] predict two interacting flow components and describe warm, shallow on-axis and hot, deep off-axis hydrothermal circulation. Our data suggest that interacting flow components could also be existent for Aurora Vent Field.

In general, lateral variations, particularly near discharge zones, are found to be $100 \mathrm{~s}$ to $10,000 \mathrm{~s} \mathrm{~m} \mathrm{~m}^{-2}$ over a few meters [52]. Hydrothermal processes at oceanic spreading centers account for approximately $10 \%$ of all heat flow in the oceans, control the thermal structure of young oceanic plates, influence ocean and crustal chemistry, and therefore provide a crucial constraint for (chemosynthetic) ecosystems and global heat loss calculations $[52,69,70]$. The data presented in this manuscript are available on the pangaea data repository and in the Antarctic Geothermal Heat Flow database [42].

\section{Conclusions}

For three different geological settings, we have demonstrated that thermal in situ observations hold clues toward the development of a better understanding of the processes linking visco-elastic behavior of the crust, tectonic fragmentation and ocean basin formation, mantle dynamics, and hydrothermal venting (cooling of the lithosphere). Yet, 
a fundamental limitation for GHF estimation in polar regions is the lack of in situ data for validation of indirect models [2].

- Geothermal heat flow models of and around the Antarctic Peninsula show high discrepancies. Our observations across the western Weddell Sea shelf, particularly around James Ross Island indicate elevated geothermal gradients. The estimated heat flow ranges from $75 \pm 5 \mathrm{~mW} \mathrm{~m}^{-2}$ to $139 \pm 26 \mathrm{~mW} \mathrm{~m}^{-2}$. We therefore suggest to consider these values for future heat flow models, analyses of ice sheet dynamics, and studies of the visco-elasticity in the region.

- The northern part of the Powell Basin around the bathymetric high yields heat flow values within the expected range of oceanic crust with ages between 32 to $18 \mathrm{Ma}$ (Figure 11). Maximum GHF values might reach up to $92 \mathrm{~mW} \mathrm{~m}^{-2}$, after considerations of a thermal blanketing effect induced by high sedimentation rates.

- In situ thermal observations from the Western Volcanic Zone of the Gakkel Ridge, in particular around the Aurora Vent Field, reveal a complex distribution of GHF patterns, which are likely correlated to the hydrothermal activity. The distribution suggests varying heat sources and that the largest heat source might not be located directly beneath the volcanic mount, but towards the ridge center. The anomalous behavior of ultra-slow spreading ridges is not well represented in model predictions of seafloor age, depth, and heat flow (Figure 11). Ultra-slow spreading ridges might contribute stronger to global heat loss, than previously thought.

The studies in geology, geophysics, and glaciology have sought to constrain geothermal heat flow, with a developing dedicated multinational and interdisciplinary community. Geophysical methods remain the most promising approach for estimation of GHF, but the largest in the models stem from uncertain composition and structure of the lithosphere and mantle. Borehole-derived estimates are therefore urgently required to validate and ground-truth existing models.

Supplementary Materials: The following are available online at https:/ / www.mdpi.com/2076-326 3/11/1/11/s1, The geothermal heat flow data set of PS118 will be added to the Antarctic Geothermal Heat Flow database available at https://github.com/RicardaDziadek/Antarctic-GHF-DB after publication or from the authors upon request (ricarda.dziadek@awi.de). The PS86 and PS118 heat flow dataset are hosted on the Pangaea database (www.pangaea.de) and in the supplementary information to this manuscript.

Author Contributions: Conceptualization, writing—original draft preparation, visualization R.D.; investigation and data acquisition, R.D., M.D., F.W.; supervision, project administration, funding acquisition, V.S. All authors have read and agreed to the published version of the manuscript.

Funding: This work was supported by the Deutsche Forschungsgemeinschaft (DFG) in the framework of the priority program "Antarctic research with comparative investigations in Arctic ice areas" by grant GO 724/14-1. Additional funds were contributed by the AWI Research Program PACES-II and its Workpackage 3.2. The study contributes to the Scientific Program “Past Antarctic Ice Sheet Dynamics" (PAIS) of the Scientific Committee for Antarctic Research (SCAR). RD was funded through the AWI-MARUM Helmholtz Excellence Network The Polar System and its effects on the Ocean Floor and expedition funds where contributed by grant AWI_PS118_03.

Institutional Review Board Statement: Not applicable.

Informed Consent Statement: Not applicable.

Data Availability Statement: Data available in a publicly accessible repository

Acknowledgments: We express our gratitude to the RV Polarstern Crew and scientific party of PS86 and PS118 for their support, endless engagement and creative thinking in unforeseen situations. We thank two anonymous reviewer for their constructive comments, which benefited the manuscript considerably.

Conflicts of Interest: The authors declare no conflict of interest. 


\section{References}

1. Montési, L.G.J.; Behn, M.D. Mantle flow and melting underneath oblique and ultraslow mid-ocean ridges. Geophys. Res. Lett. 2007, 34, 1-5. [CrossRef]

2. Standish, J.J.; Dick, H.J.B.; Michael, P.J.; Melson, W.G.; O’Hearn, T. MORB generation beneath the ultraslow spreading Southwest Indian Ridge (9-25 E): Major element chemistry and the importance of process versus source. Geochemistry, Geophys. Geosystems 2008, 9. [CrossRef]

3. Schlindwein, V.; Schmid, F. Mid-ocean-ridge seismicity reveals extreme types of ocean lithosphere. Nature 2016, 535, 276-279. [CrossRef] [PubMed]

4. Bown, J.W.; White, R.S. Variation with spreading rate of oceanic crustal thickness and geochemistry. Earth Planet. Sci. Lett. 1994, 121, 435-449. [CrossRef]

5. German, C.R.; Baker, E.T.; Mevel, C.; Tamaki, K. the FUJI Science Team Hydrothermal activity along the southwest Indian ridge. Nature 1998, 395, 490-493. [CrossRef]

6. Boetius, A. The Expedition PS86 of the Research Vessel POLARSTERN to the Arctic Ocean in 2014; Alfred Wegener Institute for Polar and Marine Research: Bremerhaven, Germany, 2015.

7. Edmonds, H.N.; Michael, P.J.; Baker, E.T.; Connelly, D.P.; Snow, J.E.; Langmuir, C.H.; Dick, H.J.B.; Mühe, R.; German, C.R.; Graham, D.W. Discovery of abundant hydrothermal venting on the ultraslow-spreading Gakkel ridge in the Arctic Ocean. Nature 2003, 421, 252-256. [CrossRef]

8. Chown, S.L.; Lee, J.E.; Hughes, K.A.; Barnes, J.; Barrett, P.J.; Bergstrom, D.M.; Convey, P.; Cowan, D.A.; Crosbie, K.; Dyer, G.; et al. Challenges to the future conservation of the Antarctic. Science 2012, 337, 158-159. [CrossRef]

9. Burton-Johnson, A.; Dziadek, R.; Martin, C.; Halpin, J.; Whitehouse, P.L.; Ebbing, J.; Martos, Y.M.; Martin, A.; Schroeder, D.; Shen, W.; et al. Antarctic Geothermal Heat Flow: Future Research Directions. Available online: file:///C:/Users/MDPI/AppData/ Local/Temp/SCAR-SERCEGeothermalHeatFlowWhitePaper-1.pdf (accessed on 14 December 2020).

10. Dorschel, B. The Expedition PS118 of the Research Vessel POLARSTERN to the Weddell Sea in 2019; Alfred Wegener Institute for Polar and Marine Research: Bremerhaven, Germany, 2019; 149p.

11. Rignot, E.; Mouginot, J.; Scheuchel, B. Ice Flow of the Antarctic Ice Sheet. Sciences 2011, 333, 1427-1430. [CrossRef]

12. Scheuchl, B.; Mouginot, J.; Rignot, E.-J.; Small, D.; Khazendar, A.; Seroussi, H.-L.; Kellndorfer, J.-M. Ice velocity and SAR backscatter record for the Antarctic Peninsula. AGU Fall Meet. Abstr. 2017.

13. Mulvaney, R.; Abram, N.J.; Hindmarsh, R.C.A.; Arrowsmith, C.; Fleet, L.; Triest, J.; Sime, L.C.; Alemany, O.; Foord, S. Recent Antarctic Peninsula warming relative to Holocene climate and ice-shelf history. Nature 2012, 489, 141-144. [CrossRef]

14. Zagorodnov, V.; Nagornov, O.; Scambos, T.A.; Muto, A.; Mosley-Thompson, E.; Pettit, E.C.; Tyuflin, S. Borehole temperatures reveal details of 20th century warming at Bruce Plateau, Antarctic Peninsula. Cryosphere 2012, 6, 675-686. [CrossRef]

15. Shen, W.; Wiens, D.A.; Lloyd, A.J.; Nyblade, A.A. A Geothermal Heat Flux Map of Antarctica Empirically Constrained by Seismic Structure. Geophys. Res. Lett. 2020, 47, 1-8. [CrossRef]

16. Martos, Y.M.; Catalan, M.; Jordan, T.A.; Golynsky, A.; Golynsky, D.; Eagles, G.; Vaughan, D.G. Heat flux distribution of Antarctica unveiled. Geophys. Res. Lett. 2017. [CrossRef]

17. Shapiro, N.; Ritzwoller, M.H. Inferring surface heat flux distributions guided by a global seismic model: particular application to Antarctica. Earth Planet. Sci. Lett. 2004, 223, 213-224. [CrossRef]

18. An, M.; Wiens, D.A.; Zhao, Y.; Feng, M.; Nyblade, A.; Kanao, M.; Li, Y.; Maggi, A.; Lévêque, J. Temperature, lithosphereasthenosphere boundary, and heat flux beneath the Antarctic Plate inferred from seismic velocities. J. Geophys. Res. Solid Earth 2015, 120, 8720-8742. [CrossRef]

19. Morlighem, M.; Rignot, E.; Binder, T.; Blankenship, D.; Drews, R.; Eagles, G.; Eisen, O.; Ferraccioli, F.; Forsberg, R.; Fretwell, P.; et al. Deep glacial troughs and stabilizing ridges unveiled beneath the margins of the Antarctic ice sheet. Nat. Geosci. 2019. [CrossRef]

20. Michael, P.J.; Langmuir, C.H.; Dick, H.J.B.; Snow, J.E.; Goldstein, S.L.; Graham, D.W.; Lehnert, K.; Kurras, G.; Jokat, W.; Mühe, R.; et al. Magmatic and amagmatic seafloor generation at the ultraslow-spreading Gakkel ridge, Arctic Ocean. Nature 2003, 423, 956-961. [CrossRef]

21. Jakobsson, M.; Mayer, L.; Coakley, B.; Dowdeswell, J.A.; Forbes, S.; Fridman, B.; Hodnesdal, H.; Noormets, R.; Pedersen, R.; Rebesco, M.; et al. The International Bathymetric Chart of the Arctic Ocean (IBCAO) Version 3.0. Geophys. Res. Lett. 2012, 39, 1-6. [CrossRef]

22. Pfender, M.; Villinger, H. Miniaturized data loggers for deep sea sediment temperature gradient measurements. Mar. Geol. 2002, 186, 557-570. [CrossRef]

23. Decagon Devices Inc. KD2 Pro Thermal Properties Analyzer, Operator's Manual 2012; Decagon Devices Inc.: Washington, DC, USA, 2012 ; p. 68.

24. Hartmann, A.; Villinger, H. Inversion of marine heat flow measurements by expansion of the temperature decay function. Geophys. J. Int. 2002, 148, 628-636. [CrossRef]

25. Villinger, H.; Davis, E.E. A new reduction algorithm for marine heat flow measurements. J. Geophys. Res. 1987, $92,12846$. [CrossRef]

26. Fourier, J.B.J. Théorie analytique de la chaleur; Chez Firmin Didot, père et Fils: Paris, France, 1822; ISBN 9780511693205.

27. Müller, C.; Usbeck, R.; Miesner, F. Temperatures in shallow marine sediments: Influence of thermal properties, seasonal forcing, and man-made heat sources. Appl. Therm. Eng. 2016, 108, 20-29. [CrossRef] 
28. Haggerry, S.E. Mineralogical constraints on curie isotherms in deep crustal magnetic anomalies. Geophys. Res. Lett. 1978, 5, 105-108. [CrossRef]

29. Okubo, Y.; Graf, R.J.; Hansen, R.O.; Ogawa, K.; Tsu, H. Curie point depths of the Island of Kyushu and surrounding areas, Japan. GEOPHYSICS 1985, 50, 481-494. [CrossRef]

30. Fox Maule, C.; Purucker, M.E.; Olsen, N.; Mosegaard, K. Heat Flux Anomalies in Antarctica Revealed by Satellite Magnetic Data. Sciences 2005, 309, 464-467. [CrossRef]

31. Bansal, A.R.; Anand, S.P.; Rajaram, M.; Rao, V.K.; Dimri, V.P. Depth to the bottom of magnetic sources (DBMS) from aeromagnetic data of Central India using modified centroid method for fractal distribution of sources. Tectonophysics 2013, 603, 155-161. [CrossRef]

32. Li, C.F.; Lu, Y.; Wang, J. A global reference model of Curie-point depths based on EMAG2. Sci. Rep. 2017, 7. [CrossRef]

33. Spector, A.; Grant, F.S. Statistical Models for Interpreting Aeromagnetic Data. Geophysics 1970, 35, 293-302. [CrossRef]

34. Tanaka, A.; Okubo, Y.; Matsubayashi, O. Curie point depth based on spectrum analysis of the magnetic anomaly data in East and Southeast Asia. Tectonophysics 1999, 306, 461-470. [CrossRef]

35. Maus, S.; Barckhausen, U.; Berkenbosch, H.; Bournas, N.; Brozena, J.; Childers, V.; Dostaler, F.; Fairhead, J.D.; Finn, C.; Von Frese, R.R.B.; et al. EMAG2: A 2-arc min resolution Earth Magnetic Anomaly Grid compiled from satellite, airborne, and marine magnetic measurements. Geochem. Geophys. Geosyst. 2009, 10. [CrossRef]

36. Dziadek, R.; Gohl, K.; Kaul, N. Elevated geothermal surface heat flow in the Amundsen Sea Embayment, West Antarctica. Earth Planet. Sci. Lett. 2019, 506, 530-539. [CrossRef]

37. Civile, D.; Lodolo, E.; Vuan, a.; Loreto, M.F. Tectonics of the Scotia-Antarctica plate boundary constrained from seismic and seismological data. Tectonophysics 2012, 550-553, 17-34. [CrossRef]

38. Jaupart, C.; Mareschal, J.-C. Heat Flow and Thermal Structure of the Lithosphere. In Treatise on Geophysics; Schubert, G., Ed.; Elsevier: Amsterdam, The Netherlands, 2007; pp. 217-252. ISBN 978-0-444-52748-6.

39. Burton-Johnson, A.; Halpin, J.A.; Whittaker, J.M.; Graham, F.S.; Watson, S.J. A new heat flux model for the Antarctic Peninsula incorporating spatially variable upper crustal radiogenic heat production. Geophys. Res. Lett. 2017, 44, 5436-5446. [CrossRef]

40. Nagao, T.; Saki, T.; Joshima, M. Heat flow measurements around the Antarctica Contribution of R/V Hakurei. Proc. japan Acad. 2002, 78, 19-23. [CrossRef]

41. Lawver, L.A.; Keller, R.A.; Fisk, M.R.; Strelin, J.A. Bransfield Strait, Antarctic Peninsula Active Extension behind a Dead Arc. In Backarc Basins: Tectonics and Magmatism; Taylor, B., Ed.; Plenum Press: New York, NY, USA, 1995; pp. 315-342.

42. Currie, C.A.; Hyndman, R.D. The thermal structure of subduction zone back arcs. J. Geophys. Res. Solid Earth 2006, 111, 1-22. [CrossRef]

43. Elliot, D.H. Tectonic setting and evolution of the James Ross Basin, northern Antarctic Peninsula. Geol. Soc. Am. Mem. 1988, 169, 541-555.

44. Rignot, E.; Mouginot, J.; Scheuchl, B.; Van den Broeke, M.; Van Wessem, M.J.; Morlighem, M. Four decades of Antarctic Ice Sheet mass balance from 1979-2017. Proc. Natl. Acad. Sci. USA 2019, 116, 1095-1103. [CrossRef]

45. Rott, H.; Skvarca, P.; Nagler, T. Rapid collapse of northern Larsen Ice Shelf, Antarctica. Sciences 1996, 271, 788-792. [CrossRef]

46. Rack, W.; Rott, H. Pattern of retreat and disintegration of the Larsen B ice shelf, Antarctic Peninsula. Ann. Glaciol. 2004, 39, 505-510. [CrossRef]

47. Nield, G.A.; Barletta, V.R.; Bordoni, A.; King, M.A.; Whitehouse, P.L.; Clarke, P.J.; Domack, E.; Scambos, T.A.; Berthier, E. Rapid bedrock uplift in the Antarctic Peninsula explained by viscoelastic response to recent ice unloading. Earth Planet. Sci. Lett. 2014, 397, 32-41. [CrossRef]

48. Burton-Johnson, A.; Dziadek, R.; Martin, C. Geothermal heat flow in Antarctica: current and future directions. Cryosph. Discuss. 2020, 1-45. [CrossRef]

49. Rodriguez-Fernandez, J.; Balanya, J.C.; Galindo-Zaldivar, J.; Maldonado, A. Tectonic evolution of a restricted ocean basin: The powell basin (northeastern antarctic peninsula). Geodin. Acta 1997, 10, 159-174. [CrossRef]

50. Viseras, C.; Maldonado, A. Facies architecture, seismic stratigraphy and development of a high-latitude basin: The Powell Basin (Antarctica). Mar. Geol. 1999, 157, 69-87. [CrossRef]

51. Lawver, L.A.; Williams, T.; Sloan, B. Seismic stratigraphy and heat flow of Powell Basin. Terra Antarct. 1994, 1, 309-310.

52. Hasterok, D.; Chapman, D.S.; Davis, E.E. Oceanic heat flow: Implications for global heat loss. Earth Planet. Sci. Lett. 2011, 311, 386-395. [CrossRef]

53. Lindeque, A.; Martos Martin, Y.M.; Gohl, K.; Maldonado, A. Deep-sea pre-glacial to glacial sedimentation in the Weddell Sea and southern Scotia Sea from a cross-basin seismic transect. Mar. Geol. 2013, 336, 61-83. [CrossRef]

54. Catalán, M.; Martos, Y.M.; Perez, L.F.; Bohoyo, F. Unveiling Powell Basin's Tectonic Domains and Understanding Its Abnormal Magnetic Anomaly Signature. Is Heat the Key? Front. Earth Sci. 2020, 8, 1-15. [CrossRef]

55. Grose, C.J.; Afonso, J.C. Comprehensive plate models for the thermal evolution of oceanic lithosphere. Geochem. Geophys. Geosystems 2013, 14, 3751-3778. [CrossRef]

56. Mouginot, J.; Rignot, E.; Scheuchl, B. Sustained increase in ice discharge from the Amundsen Sea Embayment, West Antarctica, from 1973 to 2013. Geophys. Res. Lett. 2014, 41, 1576-1584. [CrossRef]

57. Dick, H.J.B.; Lin, J.; Schouten, H. An ultraslow-spreading class of ocean ridge. Nature 2003, 426, 405-412. [CrossRef] 
58. DeMets, C.; Gordon, R.G.; Argus, D.F.; Stein, S. Effect of recent revisions to the geomagnetic reversal time scale on estimates of current plate motions. Geophys. Res. Lett. 1994, 21, 2191-2194. [CrossRef]

59. Snow, J.E.; Edmonds, H.N. Ultraslow-Spreading Ridges Rapid Paradigm Changes. Oceanography 2007, 20, 90-101. [CrossRef]

60. Müller, R.D.; Seton, M.; Zahirovic, S.; Williams, S.E.; Matthews, K.J.; Wright, N.M.; Shephard, G.E.; Maloney, K.T.; Barnett-Moore, N.; Hosseinpour, M.; et al. Ocean Basin Evolution and Global-Scale Plate Reorganization Events since Pangea Breakup. Annu. Rev. Earth Planet. Sci. 2016, 44, 107-138. [CrossRef]

61. Beaulieu, S.E.; Szafranski, K. InterRidge Global Database of Active Submarine Hydrothermal Vent Fields, Version 3.4. Available online: http:/ /vents-data.interridge.org (accessed on 20 October 2020).

62. Lucazeau, F. Analysis and mapping of an updated terrestrial heat flow dataset. Geochem. Geophys. Geosyst. 2019, 20, 4001-4024. [CrossRef]

63. Jokat, W.; Schmidt-Aursch, M.C. Geophysical characteristics of the ultraslow spreading Gakkel Ridge, Arctic Ocean. Geophys. J. Int. 2007, 168, 983-998. [CrossRef]

64. Martos, Y.M.; Jordan, T.A.; Catalan, M.; Jordan, T.M.; Bamber, J.L.; Vaughan, D.G. Geothermal heat flux reveals the Iceland hotspot track underneath Greenland. Geophys. Res. Lett. 2018. [CrossRef]

65. Andrés, J.; Marzán, I.; Ayarza, P.; Martí, D.; Palomeras, I.; Torné, M.; Campbell, S.; Carbonell, R. Curie Point Depth of the Iberian Peninsula and Surrounding Margins. A Thermal and Tectonic Perspective of its Evolution. J. Geophys. Res. Solid Earth 2018, 123, 2049-2068. [CrossRef]

66. Sauter, D.; Carton, H.; Mendel, V.; Munschy, M.; Rommevaux-Jestin, C.; Schott, J.J.; Whitechurch, H. Ridge segmentation and the magnetic structure of the Southwest Indian Ridge (at $50^{\circ} 30^{\prime} \mathrm{E}, 55^{\circ} 30^{\prime} \mathrm{E}$ and $66^{\circ} 20^{\prime} \mathrm{E}$ ): Implications for magmatic processes at ultraslow-spreading centers. Geochem. Geophys. Geosyst. 2004, 5. [CrossRef]

67. Urlaub, M.; Schmidt-Aursch, M.C.; Jokat, W.; Kaul, N. Gravity crustal models and heat flow measurements for the Eurasia Basin, Arctic Ocean. Mar. Geophys. Res. 2009, 30, 277-292. [CrossRef]

68. Tao, C.; Seyfried, W.E.; Lowell, R.P.; Liu, Y.; Liang, J.; Guo, Z.; Ding, K.; Zhang, H.; Liu, J.; Qiu, L.; et al. Deep high-temperature hydrothermal circulation in a detachment faulting system on the ultra-slow spreading ridge. Nat. Commun. 2020, 11. [CrossRef] [PubMed]

69. Hasenclever, J.; Theissen-Krah, S.; Rüpke, L.H.; Morgan, J.P.; Iyer, K.; Petersen, S.; Devey, C.W. Hybrid shallow on-axis and deep off-axis hydrothermal circulation at fast-spreading ridges. Nature 2014, 508, 508-512. [CrossRef] [PubMed]

70. Stein, C.A.; Stein, S. Constraints on Hydrothermal Heat-Flux Through the Oceanic Lithosphere From Global Heat-Flow. J. Geophys. Res. 1994, 99, 3081-3095. [CrossRef] 